\title{
Data report: lithologic diversity, mineral composition, and temperature and redox conditions in ODP/IODP Hole 1256D-a study of sand and gravels recovered during IODP Expedition $335^{1}$
}

\author{
Bénédicte Abily ${ }^{2,3}$ and Marie Python ${ }^{4}$
}

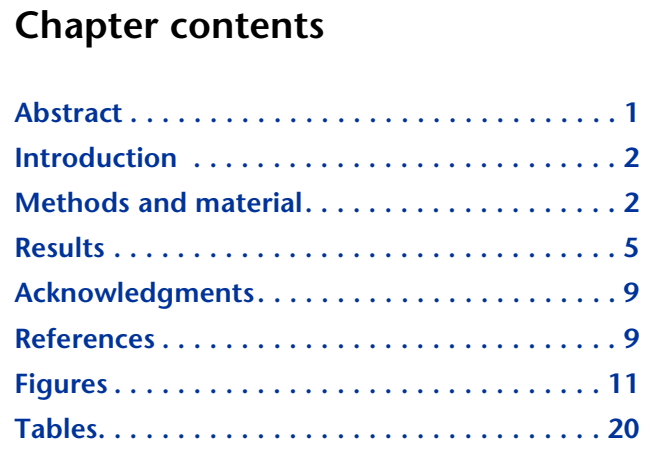

${ }^{1}$ Abily, B., and Python, M., 2016. Data report: lithologic diversity, mineral composition, and temperature and redox conditions in ODP/IODP Hole 1256D—a study of sand and gravels recovered during IODP Expedition 335. In Teagle, D.A.H., Ildefonse, B., Blum, P., and the Expedition 335 Scientists, Proc. IODP, 335: Tokyo (Integrated Ocean Drilling Program Management International, Inc.).

doi:10.2204/iodp.proc.335.203.2016

${ }^{2}$ Australian Research Council Centre of Excellence for Core to Crust Fluid Systems/GEMOC, Department of Earth and Planetary Sciences, Macquarie University, Sydney NSW 2109, Australia. benedicte.abily@gmail.com ${ }^{3}$ Also at Géosciences Environnement Toulouse (GET), Observatoire Midi Pyrénées, Université de Toulouse, CNRS, IRD, 14 avenue Edouard Belin, 31400 Toulouse, France.

${ }^{4}$ Hokkaido University, Department of Natural History Sciences, Division of Earth and Planetary Systems Sciences, North 10, West 8, Kita-ku, Sapporo 060-0810, Japan.

\section{Abstract}

This data report presents an uncommon study of fine drill cuttings (sand and gravels) recovered from hole maintenance operations in Ocean Drilling Program/Integrated Ocean Drilling Program (IODP) Hole 1256D (East Pacific Rise) during Expedition 335. Drill cuttings represent an integrated sampling of the entire hole and offer the opportunity to study the petrological characteristics of the various lithologies making up the upper oceanic crust. We selected the fine-grained fraction of cuttings coming from 12 pipe deployments (runs) and conducted microscopic observations (mineralogy and texture), image processing, electron microprobe analyses ( 4400 analyses), and oxythermobarometry calculations on 16-25 grain-mount thin sections.

This study shows that drill cuttings sample all of the lithologies in the hole (glass, aphyric and phyric basalts, dolerite, gabbro, diorite, gabbronorite, albitite, and three kinds of granoblastic basalt) but overrepresent non- or poorly recovered materials like albitites and granoblastic basalts. Drill cuttings are thus a good alternative to study these "rare" lithologies. Based on the composition of the main minerals and the oxythermobarometry calculations, two major lithologic groups were defined in the cuttings: a basaltic lavas-dolerites group and a gabbroic lithologies-granoblastic basalts group. Basaltic lavas (glass and basalts) and dolerites are characterized by $\mathrm{Mg}$-augites rich in $\mathrm{Al}_{2} \mathrm{O}_{3}, \mathrm{Cr}_{2} \mathrm{O}_{3}$, and $\mathrm{TiO}_{2} ; \mathrm{MgO}$-rich plagioclases with a mean composition of $\mathrm{An}_{60-70}$; and titanomagnetites. Their Fe-Ti oxides (magnetite and ilmenite) indicate relatively reducing conditions ( $\triangle \mathrm{NNO}=-1.26$ to -0.80 ), and clinopyroxenes in dolerites give a mean equilibrium temperature of $1017^{\circ} \mathrm{C}$. Gabbroic lithologies and granoblastic basalts are characterized by Ca-rich clinopyroxenes (augites and diopsides) depleted in $\mathrm{Al}_{2} \mathrm{O}_{3}, \mathrm{Cr}_{2} \mathrm{O}_{3}$, and $\mathrm{TiO}_{2} ; \mathrm{MgO}$-poor plagioclases with a mean composition of $\mathrm{An}_{50-60}$; and Ti-poor magnetites. Oxybarometers give oxidizing $(\triangle \mathrm{NNO}=-0.08$ to +0.58 ) to very oxidizing $(\Delta \mathrm{NNO}=+1.97$ to +2.38$)$ conditions for these lithologies, and their pyroxenes indicate high $\left(909^{\circ} \mathrm{C}-985^{\circ} \mathrm{C}\right)$ to relatively high $\left(783^{\circ} \mathrm{C}-888^{\circ} \mathrm{C}\right)$ mean temperatures according to the thermometer considered. Albitites show equivalent mineral compositions and temperature and redox conditions to gabbroic lithologies and granoblastic basalts. They are, however, characterized by albitic plagioclases $\left(\mathrm{An}_{0-20}\right)$ and usually display slightly lower temperatures $\left(780^{\circ} \mathrm{C}\right)$ and higher $\Delta \mathrm{NNO}$ values $(+2.66)$. One grain of gabbro 
(Run14EXJB-T-G15) strongly differs from the other gabbroic grains ( 40 grains) in terms of clinopyroxene composition, temperature, and oxidation state. This gabbro has thus probably suffered from peculiar processes compared to the other gabbroic lithologies.

\section{Introduction}

Integrated Ocean Drilling Program (IODP) Expedition 335 (April-May 2011) was the fourth scientific drilling expedition to Hole 1256D (after Ocean Drilling Program Leg 206 and IODP Expeditions 309 and 312 ) and aimed to reach ocean crust Layer 3. Hole $1256 \mathrm{D}$ is located at $6.736^{\circ} \mathrm{N}, 91.934^{\circ} \mathrm{W}$, in the eastern equatorial Pacific Ocean in $\sim 15$ Ma crust that formed at the East Pacific Rise at a superfast spreading rate (>200 mm/y) (Wilson, 1996). This hole currently represents the only continuous section of fastspread upper oceanic crust ever drilled in modern oceans.

The previous expedition (312) deepened the hole to 1507.1 meters below seafloor (mbsf) and reached the sheeted-dike/gabbro transition zone for the first time (Teagle, Alt, Umino, Miyashita, Banerjee, Wilson, and the Expedition 309/312 Scientists, 2006). Expedition 335 aimed to deepen the hole into the cumulate gabbros, a unit poorly known at present-day fast-spreading ridges (see the "Expedition 335 summary" chapter [Expedition 335 Scientists, 2012a]). However, owing to collapse events during drilling operations and to the toughness of recrystallized rocks located at the sheeted-dike/gabbro transition zone (i.e., granoblastic basalts), only five cores with $<15 \%$ recovery were drilled to 1521.6 mbsf during Expedition 335. Nevertheless, a unique and huge collection of samples $(\sim 50 \mathrm{~kg})$, including large cobbles (up to $4.5 \mathrm{~kg}$ ), centimeter-sized pebbles, and very fine to coarse-grained sand and gravels were recovered during cleaning operations (see the "Expedition 335 summary" chapter [Expedition 335 Scientists, 2012a]).

Sand and gravels correspond to fine-grained cuttings coming from various depths in the borehole since the first drilling expedition (Leg 206) and recovered in the junk baskets associated with the drill bit (see "Operations" in the "Expedition 335 summary" chapter [Expedition 335, Scientists, 2012a]). They represent an integrated sampling of the entire hole from the lava sequence to the plutonic section. Even if the depth from which the cuttings fell is unknown, their study is a good opportunity to make a comprehensive review of the various lithologies present in the hole.
During Expedition 335, a petrographic study was initiated on fine-grained cuttings coming from two fishing runs (i.e., pipe deployment recovering cuttings during hole cleaning operations). Six grainmount thin sections were grain counted, and the lithology of each grain was identified to establish the nature of the fine-grained cuttings (Fig. F4 in the "Site 1256" chapter [Expedition 335 Scientists, 2012c]). The present report completes this preliminary work by studying sand and gravels from more fishing runs and by undertaking electron microprobe analyses on these cuttings. However, a different petrographic approach than the one employed on board the ship was applied: (1) we conducted a more detailed petrographic identification of the grains in order to study the lithologic diversity of the cuttings and (2) we applied a method using the area of the grains instead of the number of grains to estimate the abundance of each lithology in order to reduce underestimations related to grain size variations. From mineral composition, we also conducted thermometry and oxybarometry calculations on the cuttings to estimate the temperature and redox conditions prevailing at different levels in the hole.

This study provides a unique, significant, and robust database linking the lithology, mineral composition ( 4400 analyses), temperature, and oxidation state of the upper crust at a modern fast-spreading ridge and will be useful (1) for comparison with other drilled and dredged oceanic sites and with fossil-exposed mid-ocean ridges (ophiolites) and (2) for understanding the magmatic, metamorphic, and hydrothermal processes occurring at fast-spreading ridges.

\section{Methods and material Samples}

\section{Selection}

We selected sand and gravels from 12 fishing runs over the 14 conducted during hole cleaning operations (Table T1). Runs 2 and 6 recovered cuttings from an unstable section of the hole located in the lava sequence ( 922 mbsf), whereas the other runs (11-15 and 17-21) recovered cuttings from the bottom of the hole (1518-1520.2 mbsf) (see Table T1 in the "Site 1256" chapter [Expedition 335 Scientists, $2012 c]$ ). For each fishing run, the fine-grained fraction of the cuttings (grain size from $\sim 0.5$ to $5 \mathrm{~mm}$ ) was sampled to rule out single mineral grains or mixed grains and to have sufficient grains per thin section for good statistics. For Runs 12, 15, and 19, we selected two different fine-grained fractions (coarser and finer), and for Run 20 we selected cut- 
tings from various fishing assemblies (bit sub junk basket [BSJB] and external junk basket 1 [EXJB1]) (Table T1).

Grains were randomly selected and mounted in thin sections (Fig. F1A). A total of 25 polished thin sections were prepared with at least 2 thin sections for each run (except for Runs 2, 11, and 13) in order to evaluate the heterogeneity of the cuttings (Table T1). The number of grains per thin section varies from 24 to 400 according to the grain size, but most thin sections include around 35 grains (Table T1; Fig. F1A).

\section{Description}

The lithology of each grain was identified on the basis of its mineral paragenesis and texture, accurate modal proportions being difficult to estimate in these fine-grained cuttings. We identified 11 major lithologies: glass, aphyric basalt, phyric basalt, dolerite, gabbro, diorite, gabbronorite, albitite, and three kinds of granoblastic basalt (Fig. F1B). These lithologies are similar to those described on board the ship from Hole 1256D cores and reflect the different levels of the hole (see the "Site 1256" chapter [Expedition 335 Scientists, 2012c] and Teagle, Alt, Umino, Miyashita, Banerjee, Wilson, and the Expedition 309/312 Scientists, 2006).

Grains of fresh and devitrified glass are present in most thin sections. They sporadically include microcrysts of plagioclase $(\mathrm{pl})$ and microphenocrysts of plagioclase and clinopyroxene (cpx). Grains of basalt have microphyric to fine-grained textures. Groundmass phases consist of plagioclase, clinopyroxene, glass, and Fe-Ti oxides (magnetite and minor ilmenite). The microphenocryst phases (i.e., visible under magnification) are mainly plagioclase and clinopyroxene. Sulfides and secondary quartz are commonly observed. Basalts were classified as aphyric or phyric according to the relative abundance of microphenocrysts (see example on Fig. F1). Glass and basalt grains likely come from the extrusive sequence of the hole, although some grains (phyric basalts and glass) may come from the upper part of the sheeteddike complex (Teagle, Alt, Umino, Miyashita, Banerjee, Wilson, and the Expedition 309/312 Scientists, 2006).

Dolerite grains have medium- to fine-grained holocrystalline textures and are mainly composed of plagioclase, clinopyroxene, amphibole, magnetite, and ilmenite. Glass is rarely observed. Dolerite grains present variable degrees of alteration; sulfides and secondary quartz are occasionally observed. These grains most likely come from the sheeted-dike complex of the hole.

Gabbro, gabbronorite, and diorite grains have medium- to coarse-grained macrocrystalline textures and show various degrees of alteration. The main paragenesis of the gabbros is $\mathrm{cpx}+\mathrm{pl}+\mathrm{Fe}$-Ti oxides \pm amphibole \pm olivine (ol), and the main paragenesis of the gabbronorites is cpx + orthopyroxene (opx) + $\mathrm{pl}+\mathrm{Fe}-\mathrm{Ti}$ oxides \pm ol. Olivine-bearing grains are, however, very rare. Accessory phases like quartz, apatite, zircon, titanite, and sulfides are commonly observed. Diorite grains consist of clinopyroxene, amphibole, plagioclase, quartz, and Fe-Ti oxides with accessory apatite, zircon, and epidote. In all gabbroic grains, pyroxenes are variably altered to secondary amphiboles and Fe-Ti oxides correspond to ilmenite and magnetite. Most gabbroic grains probably come from the two gabbro units located in the plutonic section of the hole, but some grains may represent gabbroic dikes cutting the base of the sheeted-dike complex or the plutonic section (Teagle, Alt, Umino, Miyashita, Banerjee, Wilson, and the Expedition 309/312 Scientists, 2006).

Grains of granoblastic basalt consist of two pyroxenes, plagioclase, ilmenite, and magnetite with minor quartz, and sulfides and are characterized by recrystallized medium-grained doleritic to finegrained granular textures. Three kinds of granoblastic basalt grains were identified according to their recrystallization degree using the 0-6 textural scale defined on board the ship (see Fig. F11 in the "Methods" chapter [Expedition 335 Scientists, 2012b]). Low recrystallization degrees (1 and 2) are characterized by the growth of small, isolated micrometer-sized opx and/or cpx granules replacing clinopyroxenes. As the recrystallization proceeds, the pyroxene granules develop and the igneous texture is progressively replaced. In this way, granoblastic basalts were classified as strongly recrystallized (Degrees 3 and 4) if the igneous texture is only partially erased (i.e., laths of plagioclase and relics of primary cpx and Fe-Ti oxides) and as completely recrystallized (Degrees 5 and 6) if the igneous texture is obliterated and overprinted by an equigranular granoblastic assemblage of secondary pyroxenes, plagioclase, and Fe-Ti oxides exhibiting flat grain boundaries and $120^{\circ}$ triple junctions. Granoblastic basalt grains are usually rather fresh, although grains altered into hydrous assemblages are occasionally observed and often display amphibole and orthopyroxene veins. These granoblastic basalts were cored at the base of the sheeted-dike complex and in the plu- 
tonic section (Teagle, Alt, Umino, Miyashita, Banerjee, Wilson, and the Expedition 309/312 Scientists, 2006) and were interpreted as produced by hightemperature metamorphism of hydrothermally altered dikes (Koepke et al., 2008).

Albitite grains have strongly altered medium-grained macrocrystalline textures and essentially consist of dusty plagioclase of albitic composition with minor clinopyroxene, titanite, chlorite, apatite, epidote, and Fe-Ti oxides (ilmenite and minor magnetite). The dusty appearance of plagioclases is usually related to scattered microcrystals of hydrated calciumaluminium silicates. No quartz is observed. This kind of leucocratic rock was not reported in previous expeditions but was described in cores and pebbles/ cobbles during Expedition 335. They were interpreted on board the ship as strongly altered granoblastic basalts on the basis of textural observations (see the "Site 1256" chapter [Expedition 335 Scientists, 2012c]).

\section{Methods}

\section{Image processing}

The abundance of each lithology in each thin section was estimated using the Java-based image processing program ImageJ on high-quality photos of the thin sections (JPEG file extension, 2400-4000 dpi; Fig. F1A). First, each grain of the thin section was manually outlined and labeled according to the lithologic groups previously described. Then, the area occupied by all grains of a same lithologic group was measured in number of pixels by the program and converted into relative abundance (Fig. F1B). For a better illustration of the results, a simplified process in which each grain was labeled according to the four main lithologies defined in the hole (basaltic lavas, dolerites, gabbroic lithologies, and granoblastic basalts) was also undertaken (Fig. F1C). The "others" group corresponds to isomodal and metal grains in the detailed process and to isomodal, metal, and albitite grains in the simplified process. The results are illustrated in Figure F2.

\section{Mineral composition}

Major and minor element compositions of main mineral phases (cpx, opx, feldspar, olivine, Fe-Ti oxides, and amphibole) and glass were determined using an electron microprobe (CAMECA SX50 at Toulouse University, CAMECA SX100 at Brest University, and JEOL 8800 at Hokkaido University). A standard analysis program with an accelerating voltage of 15 $\mathrm{kV}$ and a beam current of 10-20 nA was used at Toulouse and Brest Universities. An accelerating voltage of $20 \mathrm{kV}$, a beam current of $20 \mathrm{nA}$, and a probe diameter of $3 \mu \mathrm{m}$ were used at Hokkaido University. Counting time was 10-20 s on the peak and 5-10 s on the background for both programs. Detection limits were similar for the three instruments with values of $\sim 0.07 \%$ for $\mathrm{Al}_{2} \mathrm{O}_{3}$ and $\mathrm{Na}_{2} \mathrm{O}$ and $\sim 0.09 \%$ for $\mathrm{TiO}_{2}$ and $\mathrm{Cr}_{2} \mathrm{O}_{3}$ for all phases analyzed. The full data set is available in RESULTS in "Supplementary material."

About 4400 analyses were performed on 16 grainmount thin sections. To simplify the chemical diagrams and to allow better comparison between cuttings and core data, grains were grouped into seven major lithologies: basaltic lavas (basalts and glass), dolerites, gabbroic lithologies (gabbro, gabbronorite, and diorite), albitites, and the three kinds of granoblastic basalt (low, strong, and complete recrystallization). This report aimed to make an inventory of the mineral composition of the entire hole; no distinction was made between primary (magmatic) and secondary (related to alteration or recrystallization) main phases. In the same way, the distinction between microphenocrysts and microcrysts in basaltic lava grains has not been investigated in detail; only a few obvious microphenocrysts were analyzed for comparison.

\section{Thermometry and oxybarometry}

Several geothermometers and oxybarometers were used to estimate the equilibrium temperature and redox conditions prevailing in the different levels of the hole (Table T2). The 2-pyroxene thermometers of Brey and Kohler (1990) and Andersen et al. (1993; QUILF program) were used for lithologies with coexisting cpx and opx, and the single-clinopyroxene thermometer of France et al. (2010b) was used for cpx-bearing holocrystalline rocks. For hornblendeand edenite-bearing lithologies (except basalts), we used the amphibole-plagioclase thermometer of Holland and Blundy (1994). The 2-oxide oxythermobarometers of Sauerzapf et al. (2008) and Andersen et al. (1993; QUILF program) were used to estimate the temperature and oxygen fugacity in grains with coexisting ilmenite and magnetite. The clinopyroxeneplagioclase oxybarometer of France et al. (2010a) was used to estimate the oxidation state of grains bearing this mineral pair except basalts and glasses (the model being not recommended for skeletal and dendritic crystals). To apply this oxybarometer, we used the temperatures estimated with the 2-pyroxene and single-clinopyroxene thermometers (Table T2) and the mean composition of the glass grains as an equivalent of the melt composition. For oxybarometers, the oxidation state was expressed as $\triangle \mathrm{NNO}$ (ox- 
ygen fugacity relative to the nickel-nickel-oxide buffer) and $\triangle \mathrm{FMQ}$ (oxygen fugacity relative to the fayalite-magnetite-quartz buffer).

For all calculations, we applied a pressure of $1 \mathrm{kbar}(0$ kbar for the amphibole-plagioclase thermometer) corresponding to the upper crust conditions, and we worked with average mineral compositions per grain. The results are available in RESULTS in "Supplementary material" and summarized in Table T2.

\section{Results}

\section{Lithologic abundance}

For a same run, thin sections usually show the same lithologies whatever the grain size or the fishing assembly considered (Fig. F2A). Cuttings from some runs $(6,15,17,18$, and 20) appear relatively homogeneous in terms of abundance of the main lithologies (Fig. F2B). However, for other runs (12, 14, 19, and 21), the different thin sections display significant variations in the abundance of the main lithologies, especially basaltic lavas and granoblastic basalts.

Runs 2 and 6 recovered cuttings from an unstable section of the hole located in the lava sequence ( 922 mbsf). They are thus unsurprisingly composed of more than $90 \%$ basaltic lavas (basalt and minor glass) (Fig. F2). Some dolerites (up to 7\%) are also observed in Run 6, although the top of the sheeteddike complex in the borehole is located around 1060 mbsf. This is probably related to the incomplete evacuation of cuttings from the hole during Expeditions 309/312 drilling operations.

The other runs (11-15 and 17-21) recovered cuttings from the bottom of the hole (1518-1520.2 mbsf). All the lithologies defined on board the ship are observed in these basal cuttings (Fig. F2A), confirming that they progressively accumulated in the hole since the beginning of drilling operations and thus represent an integrated sampling of the entire hole. The basal cuttings are dominated by basaltic lavas (up to 58\%, Run19BSJBc-T) and granoblastic basalts (up to 73\%, Run14EXJB-H) except in Runs 15 and 17 where basaltic lavas are rare $(<7 \%)$ and granoblastic basalts are the predominant lithologies (68\%-88\%) (Fig. F2B). Dolerites and gabbroic lithologies usually have similar and relatively low abundance in each run $(<20 \%)$; only Run 15 differs by the absence of doleritic grains. In most runs, the completely recrystallized granoblastic basalts are more abundant than other granoblastic basalts (Fig. F2A).

Albitites are observed in about one-third of the thin sections and, when present, they are relatively abundant (4\%-13\%) (Fig. F2A). The relative high propor- tion of albitite in the cuttings is quite surprising because no occurrence was reported in the hole during Expeditions 309 and 312 (Teagle, Alt, Umino, Miyashita, Banerjee, Wilson, and the Expedition 309/ 312 Scientists, 2006) and this lithology is not particularly common in the material recovered during Expedition 335 (a small piece in a core, two cobbles, and four pebbles; see the "Site 1256" chapter [Expedition 335 Scientists, 2012c]).

Taking into account all the basal cuttings studied from Runs 11-21, granoblastic basalts are the dominant lithology representing $\sim 52.5 \%$ of the cuttings, whereas dolerites are the less abundant lithology representing $\sim 6 \%$ of the cuttings. Basaltic lavas (i.e., basalts and glass) and gabbroic lithologies represent $\sim 27.5 \%$ and $\sim 10.5 \%$ of the cuttings, respectively. Within the lithologic groups, the gabbros and the completely recrystallized granoblastic basalts are the most common lithologies $(\sim 4.5 \%$ and $22 \%$ of the cuttings, respectively) (see Fig. F2). These results are very different from the lithologic abundances that we estimated from the entire hole (i.e., $64 \%$ basaltic lavas, $23 \%$ dolerites, $8 \%$ granoblastic basalts, and 5\% gabbroic lithologies) and confirm that the abundance of the lithologies in the cuttings is highly dependent of their recovery rates during drilling operations (e.g., mean recovery of $41 \%$ for basaltic lavas and $9.5 \%$ for granoblastic basalts; see Fig. F18 and Table T2 in the "Expedition 335 summary" chapter [Expedition 335 Scientists, 2012a]).

These results clearly show that cuttings sample all the lithologies of the hole but overrepresent non- or poorly cored materials (i.e., albitites, granoblastic basalts).

\section{Mineral composition}

\section{Pyroxenes}

Our database for pyroxenes consists of 1537 analyses (1053 for cpx and 484 for opx). Clinopyroxenes in basaltic lavas are mainly $\mathrm{Mg}$-augites with a mean composition of $\mathrm{En}_{49} \mathrm{Wo}_{35} \mathrm{Fs}_{15}$ and show scattered composition toward subcalcic augites and pigeonites (Wo $<30 \%$ ) and more ferrous augites (Fs > 20\%) (Fig. F3A). Microphenocrysts are mainly concentrated in the Mg-augite field; the more ferrous and less calcic pyroxenes likely reflect groundmass crystals and/or phenocryst rims (Perfit and Fornari, 1983; Dziony et al., 2008; Umino, 2007). Clinopyroxenes in dolerites are predominantly augites with variable magnesium content $(26 \%<$ En $<56 \%)$ probably reflecting core/ rim variations (Sano et al., 2011) (Fig. F3A). Some diopsides (Wo $>45 \%$ ) and rare pigeonites $\left(\mathrm{Wo}_{11-13}\right)$ are also observed. Clinopyroxenes in gabbroic lithologies and granoblastic basalts have more focused com- 
position toward diopsides and $\mathrm{Mg}$ - and Ca-rich augites (Wo > 35\%) (Fig. F3B, F3C). Rare pigeonites $\left(\mathrm{Wo}_{5-11}\right)$ and Ca-poor augites are observed. Orthopyroxenes in these lithologies are iron-rich enstatites with En contents ranging from 56\% to 68\%. Clinopyroxenes in albitites have homogeneous $\mathrm{Mg}$ - and Ca-rich compositions $\left(\mathrm{En}_{42-44} \mathrm{WO}_{42-47} \mathrm{Fs}_{9-15}\right)$ similar to cpx from gabbroic lithologies and granoblastic basalts (Fig. F3B).

Clinopyroxenes in basaltic lavas and dolerites show a wide range of composition with $\mathrm{Mg \#}$ ranging from $44 \%$ to $86 \%$ (Fig. F4). However, cpx microphenocrysts in basalts usually show primitive compositions (Mg\# > 69\%). On the contrary, cpx in gabbroic lithologies and granoblastic basalts show a limited range of composition with $\mathrm{Mg \#}$ varying from $62 \%$ to $85 \%$ (mean $\mathrm{Mg \#}$ is $~ 72 \%$ ). In these lithologies, opx also describe a limited range of composition $(58 \%<$ Mg\# < 71\%) (see RESULTS in "Supplementary material"). Clinopyroxenes in albitites have homogeneous primitive compositions with $\mathrm{Mg \#}$ ranging from $73.5 \%$ to $83.0 \%$.

From cpx compositions, two lithologic groups can be easily defined: a basaltic lavas-dolerites group and a gabbroic lithologies-granoblastic basalts group (Figs. F3, F4). For a given differentiation degree, cpx in gabbroic lithologies and granoblastic basalts are more depleted in $\mathrm{Al}_{2} \mathrm{O}_{3}, \mathrm{Cr}_{2} \mathrm{O}_{3}$, and $\mathrm{TiO}_{2}$ than cpx in basaltic lavas and dolerites (Fig. F4A-F4C). However, cpx in gabbroic lithologies are on average slightly more depleted in $\mathrm{Al}_{2} \mathrm{O}_{3}$ and $\mathrm{TiO}_{2}$ than cpx in granoblastic basalts $\left(0.8 \% \mathrm{Al}_{2} \mathrm{O}_{3}\right.$ and $0.2 \% \mathrm{TiO}_{2}$ in gabbroic lithologies and $1.1 \% \mathrm{Al}_{2} \mathrm{O}_{3}$ and $0.4 \% \mathrm{TiO}_{2}$ in granoblastic basalts) (Fig. F4B, F4C). Clinopyroxenes in albitites have compositions similar to cpx in the gabbroic lithologies-granoblastic basalts group, especially the gabbroic lithologies (Fig. F4B, F4C). However, they are on average richer in sodium (mean $\mathrm{Na}_{2} \mathrm{O}$ is $\sim 0.40 \%$ for albitites and $\sim 0.23 \%$ for gabbroic lithologies-granoblastic basalts) (Fig. F4D).

No significant chemical variation is observed in clinopyroxenes between the different kinds of granoblastic basalt and between the different gabbroic lithologies (Figs. F3C, F4; see RESULTS in "Supplementary material"). However, cpx in one gabbro grain (Run14EXJB-T-G15) clearly differ from cpx in other gabbroic grains by their high $\mathrm{Mg \#}$ $(80.5 \%-85.5 \%)$ and enstatite content $\left(\mathrm{En}_{47-49}\right)$ and their strong enrichment in $\mathrm{Cr}_{2} \mathrm{O}_{3}(0.6 \%-0.9 \%)$ and $\mathrm{Al}_{2} \mathrm{O}_{3}(2.4 \%-3.0 \%)$ for a given $\mathrm{Mg \#}$ (Figs. F3, F4A, $\mathrm{F} 4 \mathrm{C}$ ).

\section{Feldspar}

Our database for feldspar consists of 1552 analyses. All feldspars are plagioclases (Or $<10 \%)$. In most lithologic groups, plagioclases show a wide range of composition from albite $(\mathrm{An}<10 \%)$ to bytownite (An > 70\%) (Fig. F5A). These strong chemical variations are related to chemical zoning and to the coexistence of primary and secondary (i.e., resulting from alteration or recrystallization) plagioclases in all lithologies (Alt et al., 2010; Sano et al., 2011; Koepke et al., 2008).

Plagioclases in basaltic lavas show the widest range of composition from $\mathrm{An}_{0.3}$ to $\mathrm{An}_{85.4}$, but the most common composition is $\mathrm{An}_{60-70}$ (Fig. F5A). Microcrysts in glass grains and microphenocrysts usually have anorthite contents $>60 \%$ and show the most calcic compositions (An > 80\%) (Fig. F5B). The composition of plagioclases in dolerites mainly ranges from $\mathrm{An}_{42}$ to $\mathrm{An}_{83}$ (Fig. F5A; see RESULTS in "Supplementary material"). The most common composition is $\mathrm{An}_{60-70}$, and sodium-rich plagioclases (An < $30 \%)$ are rare. Most plagioclases in gabbroic lithologies have anorthite contents in the range of $50 \%-$ 60\% (Fig. F5A). Sodium-rich compositions (An < $30 \%)$ are essentially observed in plagioclases from gabbros (especially quartz-gabbros) and diorites, and ol-bearing lithologies usually have calcium-rich plagioclases $\left(\mathrm{An}_{63-76}\right)$ (Fig. F5C; see RESULTS in "Supplementary material"). Plagioclases in granoblastic basalts show relatively homogeneous compositions with $70 \%$ of the analyses falling in the range $\mathrm{An}_{50-60}$ (Fig. F5A). Plagioclases from the different kinds of granoblastic basalt display similar compositions (Fig. F5D). As previously, two lithologic groups can be identified from plagioclase compositions: a basaltic lavas-dolerites group $\left(\mathrm{An}_{60-70}\right)$ and a gabbroic lithologies-granoblastic basalts group $\left(\mathrm{An}_{50-60}\right)$. Albitites clearly differ from other lithologies by the sodiumrich composition of their plagioclases; $>90 \%$ of the analyses fall in the range $\mathrm{An}_{0-20}$ (Fig. F5A).

Plagioclases in basaltic lavas (microcrysts and microphenocrysts) and dolerites show a wide range of $\mathrm{MgO}$ contents from $0 \%$ to $0.8 \%$ with a mean value around $0.2 \%$ (Fig. F6). On the contrary, plagioclases from gabbroic lithologies and granoblastic basalts mainly have very low $\mathrm{MgO}$ contents below or close to the detection limit of the microprobe ( 0.05\%). Only some analyses show higher MgO values (up to $0.6 \%)$. Plagioclases in albitites are devoid of magnesium. This characteristic associated with their sodium-rich compositions shows that plagioclases in 
albitites are secondary phases related to alteration processes (Alt et al., 2010).

\section{Fe-Ti oxides}

Our database for Fe-Ti oxides consists of 1011 analyses. Magnetite and ilmenite solid solutions (595 and 416 analyses, respectively) are observed in all lithologic groups and coexist in about $50 \%$ of the grains (Fig. F7A). Magnetite alone is usually found in grains of basalt, dolerite, and granoblastic basalt, whereas ilmenite alone is usually found in gabbroic and albitite grains (see RESULTS in "Supplementary material").

The titanomagnetites of basaltic lavas clearly differ from the magnetites of gabbroic lithologies in having high $\mathrm{TiO}_{2}$ content $(16.6 \%-22.6 \%$ vs. $0.7 \%-7.2 \%)$ and low $\mathrm{Cr}_{2} \mathrm{O}_{3}$ content ( $0.06 \%$ vs. $0.44 \%$ on average) (Fig. F7). Magnetites in granoblastic basalts have compositions similar to those in gabbroic lithologies but are sometimes more titaniferous (up to $16 \%$ $\mathrm{TiO}_{2}$ ). Dolerites show either titanomagnetites with compositions similar to those from basaltic lavas $\left(15 \%-24 \% \mathrm{TiO}_{2}, \mathrm{Cr}_{2} \mathrm{O}_{3}<0.2 \%\right)$ or magnetites with compositions similar to those from gabbroic lithologies and granoblastic basalts $\left(1.5 \%-4.5 \% \quad \mathrm{TiO}_{2}\right.$, $0.02 \%-0.92 \% \mathrm{Cr}_{2} \mathrm{O}_{3}$ ). Albitites usually display low-Ti and high-Cr magnetites $\left(0.3 \%-5.0 \% \mathrm{TiO}_{2}\right.$ and $0.5 \%-$ $\left.1.2 \% \mathrm{Cr}_{2} \mathrm{O}_{3}\right)$, which also points to a hydrothermal origin and is in accordance with plagioclase chemistry (e.g., Abzalov, 1998). Again, a clear distinction exists between the titanomagnetites of basaltic lavasdolerites and the magnetites of gabbroic lithologiesgranoblastic basalts.

Contrary to magnetites, ilmenites do not show significant chemical variations between the different lithologies (Fig. F7A). They have quite homogeneous compositions with $\mathrm{TiO}_{2}$ and $\mathrm{MgO}$ contents ranging from $41.5 \%$ to $53.1 \%$ and $0 \%$ to $0.6 \%$, respectively, and plot on the ilmenite-rich side of the solid solution. All ilmenites are relatively manganiferous (MnO ranges from $0.5 \%$ to $5.8 \%$, see RESULTS in "Supplementary material").

No significant chemical variation is observed in Fe-Ti oxides between the different kinds of granoblastic basalt and between the different gabbroic lithologies (Fig. F7; see RESULTS in "Supplementary material").

\section{Olivine}

Only seven analyses of olivine are included in our database because of the rarity of ol-bearing grains. Olivines are exclusively observed in gabbroic grains. They have relatively evolved compositions with forsterite (Fo) contents ranging from $63.7 \%$ to $67.5 \%$ and have similar compositions in ol-gabbros and olgabbronorites (see RESULTS in "Supplementary material")

\section{Amphibole}

Our database for amphiboles consists of 103 analyses. They were analyzed in all lithologic groups except albitites (Fig. F8). All amphiboles are calcic with compositions ranging from $\mathrm{Mg}$-hornblende to actinolite and minor ferro-actinolite (Fig. F8A). Ferrohornblendes and tremolites are also observed in a few gabbros. Only two edenites were analyzed in basalt and gabbro grains (Fig. F8B). These amphiboles are mainly secondary phases resulting from the alteration of clinopyroxenes. However, the geothermometry study shows that some of them are most likely magmatic phases (see "Temperature and redox conditions").

\section{Glass}

Our database for basaltic glasses is composed of 153 analyses (76 for glass grains and 77 for groundmass glass). Fresh glasses have $\mathrm{XMg}\left(\mathrm{Mg} /\left[\mathrm{Mg}+\mathrm{Fe}^{\mathrm{T}}\right]\right)$ ranging from 0.51 to 0.60 and a mean composition of $52 \% \mathrm{SiO}_{2}, 1.1 \% \mathrm{TiO}_{2} \%, 13.9 \% \mathrm{Al}_{2} \mathrm{O}_{3}, 10.9 \% \mathrm{FeO}$, $0.2 \% \mathrm{MnO}, 7.5 \% \mathrm{MgO}, 11.4 \% \mathrm{CaO}, 2.2 \% \mathrm{Na}_{2} \mathrm{O}$, and $0.09 \% \mathrm{~K}_{2} \mathrm{O}$ (Fig. F9; see RESULTS in "Supplementary material"). Only one grain of fresh glass (Run18BSJB-G20, 5 analyses) differs from other grains, with a less siliceous and more titaniferous and alkaline composition $\left(49.6 \% \mathrm{SiO}_{2}, 1.9 \% \mathrm{TiO}_{2}\right.$, $2.7 \% \mathrm{Na}_{2} \mathrm{O}$, and $0.2 \% \mathrm{~K}_{2} \mathrm{O}$ ) (Fig. F9C, F9D). These compositions are within the range observed in midocean-ridge basalt (MORB) glasses from the Pacific Ocean (Bézos and Humler, 2005). Devitrified glasses have compositions relatively close to fresh glasses but show wider chemical variations with, for example, $\mathrm{XMg}$ and $\mathrm{CaO}$ content ranging from 0.45 to 0.75 and from $9.9 \%$ to $13.1 \%$, respectively (Fig. F9A). Glass from basalt and dolerite groundmasses show a wide range of differentiation with $\mathrm{XMg}$ and $\mathrm{SiO}_{2}$ content ranging from 0.55 to 0.75 and from $49.9 \%$ to $54.2 \%$, respectively (Fig. F9C, F9D). They have on average higher $\mathrm{XMg}(\sim 0.66)$ and higher $\mathrm{CaO}$ and $\mathrm{Al}_{2} \mathrm{O}_{3}$ contents $(\sim 12.2 \%$ and $\sim 15.7 \%$, respectively) than fresh and devitrified glasses (Fig. F9A, F9B).

\section{Temperature and redox conditions}

\section{Temperature conditions}

The single-clinopyroxene (cpx) thermometer and the 2-pyroxene (px) thermometer of Brey and Kohler (1990) give similar equilibrium temperatures for all lithologies (difference of $20^{\circ} \mathrm{C}-30^{\circ} \mathrm{C}$ on average), whereas the QUILF 2-px thermometer of Andersen et 
al. (1993) usually gives estimated temperatures $\sim 100^{\circ} \mathrm{C}$ higher than the other pyroxene thermometers (Table T2). The pyroxene data for the different kinds of granoblastic basalt give similar ranges of temperatures $\left(833^{\circ} \mathrm{C}-861^{\circ} \mathrm{C}\right.$ for the single-cpx thermometer and $966^{\circ} \mathrm{C} \pm 52^{\circ} \mathrm{C}$ to $985^{\circ} \mathrm{C} \pm 52^{\circ} \mathrm{C}$ for the QUILF 2-px thermometer), and the poorly recrystallized samples (Degrees 1 and 2) give the lowest temperatures. The single-cpx and 2-px temperatures estimated for gabbros and gabbronorites are closer but slightly lower than those calculated for the granoblastic basalts $\left(\sim 810^{\circ} \mathrm{C}\right.$ for the single-cpx thermometer and $958^{\circ} \mathrm{C} \pm 55^{\circ} \mathrm{C}$ for the QUILF 2-px thermometer). Diorites and albitites display the lowest temperatures calculated with the single-cpx thermometer $\left(780^{\circ} \mathrm{C}-799^{\circ} \mathrm{C}\right)$, whereas dolerites show the highest temperatures $\left(1017^{\circ} \mathrm{C}\right)$. The Run14EXJB-TG15 gabbro for which the cpx composition clearly differs from that of the other gabbroic lithologies (see "Mineral composition") displays a single-cpx temperature higher than that estimated for other gabbros $\left(996^{\circ} \mathrm{C}\right)$. Moreover, the only grain of ol-gabbronorite studied shows single-cpx and 2-px temperatures higher than those estimated for gabbronorites $\left(895^{\circ} \mathrm{C}\right.$ and $1040^{\circ} \mathrm{C} \pm 131^{\circ} \mathrm{C}$ for single-cpx and QUILF 2-px thermometers, respectively).

Temperatures obtained for coexisting hornblende and plagioclase in dolerites and granoblastic basalts are usually significantly lower than those estimated from pyroxenes (from $707^{\circ} \mathrm{C}$ in one doleritic grain to $776^{\circ} \mathrm{C}$ in Degree 5 granoblastic basalts). Only one amphibole-plagioclase pair in a Degree 3 granoblastic basalt gives an equilibrium temperature of $953^{\circ} \mathrm{C}$ (see RESULTS in "Supplementary material") leading to an average temperature for this lithology closer to that estimated from pyroxenes (Table T2). Amphibole-plagioclase pairs in gabbros and diorites have average temperatures closer to or higher than those estimated from pyroxenes $\left(817^{\circ} \mathrm{C}-887^{\circ} \mathrm{C}\right)$. Among this, one edenite-plagioclase pair in a dioritic grain has an equilibrium temperature of $1005^{\circ} \mathrm{C}$ (see RESULTS in "Supplementary material") that is consistent with a magmatic origin.

The 2-oxide oxythermobarometers of Sauerzapf et al. (2008) and Andersen et al. (1993; QUILF program) provide similar equilibrium temperatures for all lithologies (difference of $50^{\circ} \mathrm{C}-60^{\circ} \mathrm{C}$ on average) except for doleritic and basaltic grains (Table T2). For all lithologies, these geothermometers give the lowest temperatures. Coexisting ilmenite and magnetite in granoblastic basalts, albitites, and gabbroic lithologies have similar equilibrium temperatures, ranging from $611^{\circ} \mathrm{C}$ to $644^{\circ} \mathrm{C}$ for the Sauerzapf et al. (2008) 2-oxide thermometer and from $677^{\circ} \mathrm{C} \pm 12^{\circ} \mathrm{C}$ to $697^{\circ} \mathrm{C} \pm 119^{\circ} \mathrm{C}$ for the QUILF 2-oxide thermometer
(Table T2). For one basaltic grain, the magnetite-ilmenite pairs display equilibrium temperatures of $798^{\circ} \mathrm{C}$ and $689^{\circ} \mathrm{C} \pm 103^{\circ} \mathrm{C}$ for the Sauerzapf et al. (2008) and Andersen et al. (1993; QUILF program) 2oxide thermometers, respectively. These low temperatures most likely reflect oxide reequilibration during subsolidus cooling or hydrothermalism. In dolerites, the average temperature estimated from the Sauerzapf et al. (2008) 2-oxide geothermometer is $902^{\circ} \mathrm{C}$, close to magmatic values, but temperatures estimated from the QUILF 2-oxide thermometer is much lower $\left(716^{\circ} \mathrm{C} \pm 97^{\circ} \mathrm{C}\right)$.

These results are in agreement with previous thermometry studies conducted on cores of granoblastic basalt, gabbro, and lava from Hole 1256D (France et al., 2009; Alt et al., 2010; Koepke et al., 2011; Dziony et al., 2008).

\section{Redox conditions}

The Andersen et al. (1993; QUILF program) 2-oxide oxybarometer usually shows more reducing values than those calculated with the Sauerzapf et al. (2008) oxybarometer (0.8-1.2 log units more reduced considering that $\Delta \mathrm{NNO} \approx \Delta \mathrm{FMQ}-0.7$; Jugo et al., 2005) except for dolerites (Table T2). Redox estimates indicate highly oxidizing conditions for granoblastic basalts, gabbroic lithologies, and albitites with $\triangle \mathrm{NNO}$ values ranging from +1.97 to +2.66 (according to Sauerzapf et al., 2008) and $\triangle \mathrm{FMQ}$ values ranging from +1.49 to +2.57 (according to Andersen et al., 1993). The most oxidizing conditions are recorded in albitites, and among granoblastic basalts, the most oxidizing conditions are found in the poorly recrystallized rocks (Degrees 1 and 2). These oxidizing values significantly exceed magmatic values. Coexisting Fe-Ti oxides in dolerites and in one grain of basalt give more reducing $\triangle \mathrm{NNO}$ values of -0.80 and -1.26 ( $\triangle$ FMQ of 0.91 and -1.44 ), respectively. These values are in agreement with those obtained for coexisting magnetite and ilmenite in one sample of the Hole 1256D lava pond (Dziony et al., 2008; Koepke et al., 2008) and are within the range observed in MORB glasses (Christie et al., 1986; Bézos and Humler, 2005; Cottrell and Kelley, 2011).

The clinopyroxene-plagioclase oxybarometer of France et al. (2010a) shows lower $\triangle \mathrm{NNO}$ and $\triangle \mathrm{FMQ}$ values compared to those derived from the 2-oxide oxybarometers except for dolerites (Table T2). The different temperatures used in the calculation have little influence on the estimated $\triangle \mathrm{NNO}$ and $\Delta \mathrm{FMQ}$ values. Redox estimates for granoblastic basalts and gabbroic lithologies indicate similar and relatively oxidizing conditions with $\triangle \mathrm{NNO}$ values ranging from -0.08 to +0.58 and $\triangle \mathrm{FMQ}$ values ranging from +0.66 to +1.35 , the most oxidizing conditions being 
observed in Degree 6 granoblastic basalts. These values are still higher than magmatic values. Coexisting clinopyroxene and plagioclase in dolerites have crystallized under highly oxidizing conditions $(\triangle \mathrm{NNO}$ of +1.22 and $\triangle \mathrm{FMQ}$ of +1.95 ) that clearly differ from the oxidation state estimated from the 2-oxide oxybarometers. This could be partly related to the crystallization of plagioclase and clinopyroxene under nonequilibrium conditions in some grains (see RESULTS in "Supplementary material"). The Run14EXJB-T-G15 gabbro, which differs from other gabbroic lithologies in terms of cpx composition and single-cpx equilibrium temperatures, is also characterized by the crystallization of coexisting plagioclase and clinopyroxene under higher oxidizing conditions $(\Delta \mathrm{NNO}$ of +2.28 and $\Delta \mathrm{FMQ}$ of +3.02$)$ (Table T2). It is thus clear that this gabbro has suffered from peculiar processes compared to other gabbroic lithologies. The clinopyroxene-plagioclase pairs in the olgabbronorite also recorded high oxidizing conditions compared to the mean oxidation state of gabbronorites.

\section{Acknowledgments}

We gratefully acknowledge the Science Party, the shipboard crew, and the IODP staff of the Expedition 335. This study used samples provided by the Integrated Ocean Drilling Program (IODP). Funding for this research was partly provided by INSU/ CNRS and JDESC (postcruise funding). We are grateful to Fabienne de Parseval, Ludovic Menjot, Jean-François Ména, Hidehiko Nomura, and Kousuke Nakamura at Toulouse (France) and Hokkaido (Japan) Universities for the thin section manufacturing and to Philippe de Parseval, Sophie Gouy, and Jessica Langlade at Toulouse and Brest (France) Universities for their help during microprobe data acquisition. We also thank Lydéric France for his help with thermometers and oxybarometers and Takashi Sano for his helpful review. This is Contribution 670 from the ARC Centre of Excellence for Core to Crust Fluid Systems (http:// www.ccfs.mq.edu.au) and 1035 in the GEMOC Key Centre (http://www.gemoc.mq.edu.au).

\section{References}

Abzalov, M.Z., 1998. Chrome-spinels in gabbro-wehrlite intrusions of the Pechenga area, Kola Peninsula, Russia: emphasis on alteration features. Lithos, 43(3):109-134. http://dx.doi.org/10.1016/S0024-4937(98)00005-X

Alt, J.C., Laverne, C., Coggon, R.M., Teagle, D.A.H., Banerjee, N.R., Morgan, S., Smith-Duque, C.E., Harris, M., and Galli, L., 2010. Subsurface structure of a submarine hydrothermal system in ocean crust formed at the East Pacific Rise, ODP/IODP Site 1256. Geochemistry, Geophysics, Geosystems, 11(10):Q10010. http://dx.doi.org/ 10.1029/2010GC003144

Andersen, D.J., Lindsley, D.H., and Davidson, P.M., 1993. QUILF: a Pascal program to assess equilibria among FeMg-Mn-Ti oxides, pyroxenes, olivine, and quartz. Computers \& Geosciences, 19(9):1333-1350. http:// dx.doi.org/10.1016/0098-3004(93)90033-2

Bézos, A., and Humler, E., 2005. The $\mathrm{Fe}^{3+} / \Sigma \mathrm{Fe}$ ratios of MORB glasses and their implications for mantle melting. Geochimica et Cosmochimica Acta, 69(3):711-725. http://dx.doi.org/10.1016/j.gca.2004.07.026

Brey, G.P., and Köhler, T., 1990. Geothermobarometry in four-phase lherzolites, II. New thermobarometers, and practical assessment of existing thermobarometers. Journal of Petrology, 31(6):1353-1378. http://dx.doi.org/ 10.1093/petrology/31.6.1353

Christie, D.M., Carmichael, I.S.E., and Langmuir, C.H., 1986. Oxidation states of mid-ocean ridge basalt glasses. Earth and Planetary Science Letters, 79(3-4):397-411. http://dx.doi.org/10.1016/0012-821X(86)90195-0

Cottrell, E., and Kelley, K.A., 2011. The oxidation state of Fe in MORB glasses and the oxygen fugacity of the upper mantle. Earth and Planetary Science Letters, 305(34):270-282. http://dx.doi.org/10.1016/ j.epsl.2011.03.014

Dziony, W., Koepke, J., and Holtz, F., 2008. Data report: petrography and phase analyses in lavas and dikes from Hole 1256D (ODP Leg 206 and IODP Expedition 309, East Pacific Rise). In Teagle, D.A.H., Alt, J.C., Umino, S., Miyashita, S., Banerjee, N.R., Wilson, D.S., and the Expedition 309/312 Scientists, Proceedings of the Integrated Ocean Drilling Program, 309/312: College Station, TX (Integrated Ocean Drilling Program Management International, Inc.). http://dx.doi.org/10.2204/ iodp.proc.309312.201.2008

Expedition 335 Scientists, 2012a. Expedition 335 summary. In Teagle, D.A.H., Ildefonse, B., Blum, P., and the Expedition 335 Scientists, Proceedings of the Integrated Ocean Drilling Program, 335: Tokyo (Integrated Ocean Drilling Program Management International, Inc.). http://dx.doi.org/10.2204/iodp.proc.335.101.2012

Expedition 335 Scientists, 2012b. Methods. In Teagle, D.A.H., Ildefonse, B., Blum, P., and the Expedition 335 Scientists, Proceedings of the Integrated Ocean Drilling Program, 335: Tokyo (Integrated Ocean Drilling Program Management International, Inc.). http://dx.doi.org/ 10.2204/iodp.proc.335.102.2012

Expedition 335 Scientists, 2012c. Site 1256. In Teagle, D.A.H., Ildefonse, B., Blum, P., and the Expedition 335 Scientists, Proceedings of the Integrated Ocean Drilling Program, 335: Tokyo (Integrated Ocean Drilling Program Management International, Inc.). http://dx.doi.org/ 10.2204/iodp.proc.335.103.2012

France, L., Ildefonse, B., and Koepke, J., 2009. Interactions between magma and hydrothermal system in Oman ophiolite and in IODP Hole 1256D: fossilization of a dynamic melt lens at fast spreading ridges. Geochemistry, 
Geophysics, Geosystems, 10(10):Q10O19. http:// dx.doi.org/10.1029/2009GC002652

France, L., Ildefonse, B., Koepke, J., and Bech, F., 2010a. A new method to estimate the oxidation state of basaltic series from microprobe analyses. Journal of Volcanology and Geothermal Research, 189(3-4):340-346. http:// dx.doi.org/10.1016/j.jvolgeores.2009.11.023

France, L., Koepke, J., Ildefonse, B., Cichy, S.B., and Deschamps, F., 2010b. Hydrous partial melting in the sheeted dike complex at fast spreading ridges: experimental and natural observations. Contributions to Mineralogy and Petrology, 160(5):683-704. http://dx.doi.org/ 10.1007/s00410-010-0502-6

Holland, T., and Blundy, J., 1994. Non-ideal interactions in calcic amphiboles and their bearing on amphibole-plagioclase thermometry. Contributions to Mineralogy and Petrology, 116(4):433-447. http://dx.doi.org/10.1007/ BF00310910

Jugo, P.J., Luth, R.W., and Richards J.P., 2005. Experimental data on the speciation of sulfur as a function of oxygen fugacity in basaltic melts. Geochimica et Cosmochimica Acta, 69(2):497-503. http://dx.doi.org/10.1016/ j.gca.2004.07.011

Koepke, J., Christie, D.M., Dziony, W., Holtz, F., Lattard, D., Maclennan, J., Park, S., Scheibner, B., Yamasaki, T., and Yamazaki, S., 2008. Petrography of the dike-gabbro transition at IODP Site 1256 (equatorial Pacific): the evolution of the granoblastic dikes. Geochemistry, Geophysics, Geosystems, 9(7):Q07O09. http://dx.doi.org/ 10.1029/2008GC001939

Koepke, J., France, L., Müller, T., Faure, F., Goetze, N., Dziony, W., and Ildefonse, B., 2011. Gabbros from IODP Site 1256, equatorial Pacific: insight into axial magma chamber processes at fast spreading ocean ridges. Geochemistry, Geophysics, Geosystems, 12(9):Q09014. http:// dx.doi.org/10.1029/2011GC003655

Leake, B.E., Woolley, A.R., Arps, C.E.S, Birch, W.D., Gilbert, M.C., et al., 1997. Nomenclature of amphiboles: report of the subcommittee on amphiboles of the International Mineralogical Association, Commission on New Minerals and Mineral Names. Canadian Mineralogist, 35:219-246.
Perfit, M.R., and Fornari, D.J., 1983. Geochemical studies of abyssal lavas recovered by DSRV Alvin from eastern Galapagos Rift, Inca Transform, and Ecuador Rift, 2. Phase chemistry and crystallization history. Journal of Geophysical Research, 88(B12):10530-10550. http:// dx.doi.org/10.1029/JB088iB12p10530

Sano, T., Sakuyama, T., Ingle, S., Rodriguez, S., and Yamasaki, T., 2011. Petrological relationships among lavas, dikes, and gabbros from Integrated Ocean Drilling Program Hole 1256D: insight into the magma plumbing system beneath the East Pacific Rise. Geochemistry, Geophysics, Geosystems, 12:Q06013. http://dx.doi.org/ 10.1029/2011GC003548

Sauerzapf, U., Lattard, D., Burchard, M., and Engelmann, R., 2008. The titanomagnetite-ilmenite equilibrium: new experimental data and thermo-oxybarometric application to the crystallization of basic to intermediate rocks. Journal of Petrology, 49(6):1161-1185. http:// dx.doi.org/10.1093/petrology/egn021

Teagle, D.A.H., Alt, J.C., Umino, S., Miyashita, S., Banerjee, N.R., Wilson, D.S., and the Expedition 309/312 Scientists, 2006. Proceedings of the Integrated Ocean Drilling Program, 309/312: Washington, DC (Integrated Ocean Drilling Program Management International, Inc.). http://dx.doi.org/10.2204/iodp.proc.309312.2006

Umino, S., 2007. Data report: textural variation of Units $1256 \mathrm{C}-18$ and $1256 \mathrm{D}-1$ lava pond, with special reference to recrystallization of the base of Unit 1256C-18. In Teagle, D.A.H., Wilson, D.S., Acton, G.D., and Vanko, D.A. (Eds.), Proceedings of the Ocean Drilling Program, Scientific Results, 206: College Station, TX (Ocean Drilling Program), 1-32. http://dx.doi.org/10.2973/ odp.proc.sr.206.007.2007

Wilson, D.S., 1996. Fastest known spreading on the Miocene Cocos-Pacific plate boundary. Geophysical Research Letters, 23(21):3003-3006. http://dx.doi.org/10.1029/ 96GL02893

Initial receipt: 2 December 2014

Acceptance: 2 November 2015

Publication: 26 February 2016

MS 335-203 
Figure F1. Illustration of image processing used to estimate abundance of each lithology in Run20BSJB-T, Hole 1256 D. A. Photograph of the thin section. B. Detailed process. C. Simplified process. Npx = number of pixels, $\%=$ relative abundance. Granoblastic low, strong, complete = granoblastic basalts with various recrystallization degrees (see "Description").

A

B Detailed process

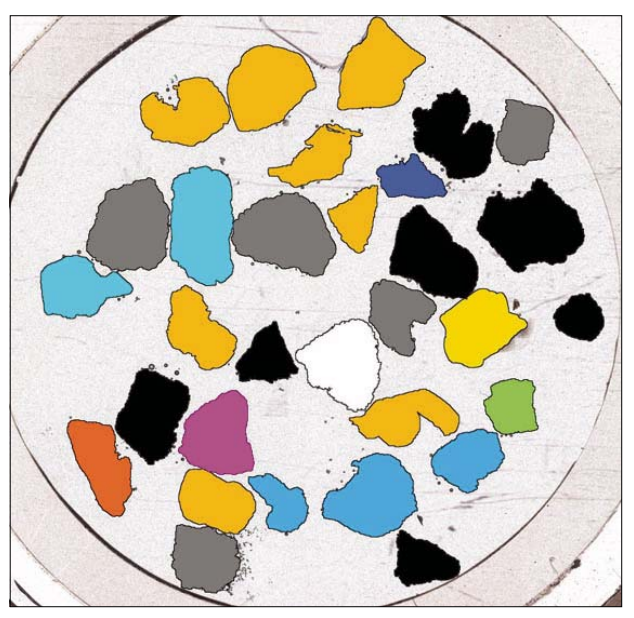

\begin{tabular}{|c|c|c|c|}
\hline Lithology & Legend & Npx & $\%$ \\
\hline Glass & & 116533 & 3.6 \\
\hline Aphyric basalts & & 801223 & 24.9 \\
\hline Phyric basalts & & 100853 & 3.1 \\
\hline Dolerites & & 62281 & 1.9 \\
\hline Gabbros & & 274814 & 8.5 \\
\hline Diorites & & 271113 & 8.4 \\
\hline Gabbronorites & & 52606 & 1.7 \\
\hline Albitites & & 122231 & 3.8 \\
\hline Granoblastic low & & 136383 & 4.2 \\
\hline Granoblastic strong & 572100 & 17.7 \\
\hline Granoblastic complete & 714517 & 22.2 \\
\hline
\end{tabular}

Run20BSJB-T thin section (plane-polarized light)

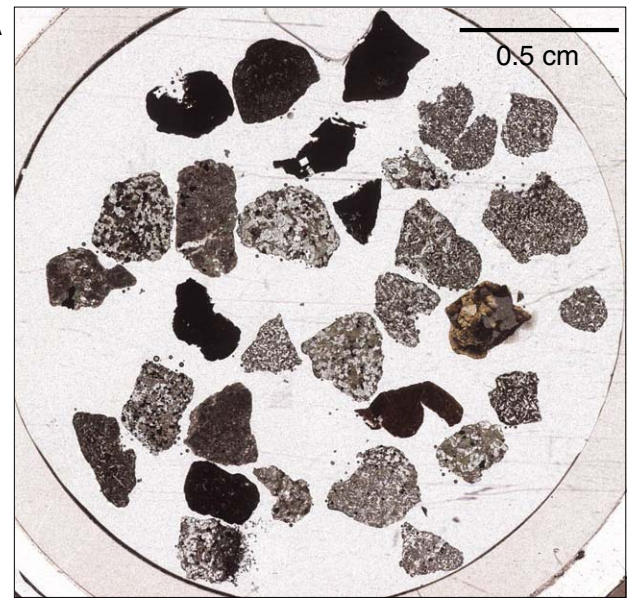

Image processing

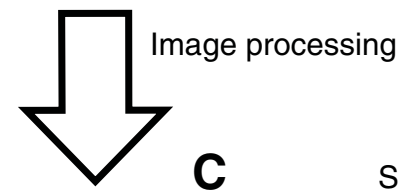

Simplified process

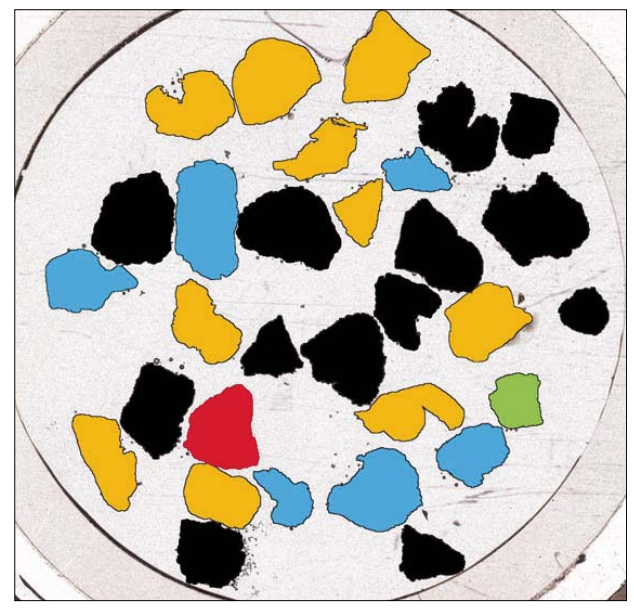

\begin{tabular}{|c|c|c|c|}
\hline Lithology & Legend & $\mathrm{Npx}$ & $\%$ \\
\hline Basaltic lavas & & 1018609 & 31.6 \\
\hline Dolerites & & 62281 & 1.9 \\
\hline Gabbroic lithologies & & 598533 & 18.6 \\
\hline Granoblastic basalts & & 1423000 & 44.1 \\
\hline Others & & 122231 & 3.8 \\
\hline
\end{tabular}


Figure F2. Image processing results showing relative abundance of each lithology in each thin section (see Table T1), Hole 1256D. A. Detailed process results (all lithologies). B. Simplified process results (four main lithologies). Basalts = aphyric and phyric basalts; granoblastic low, strong, complete $=$ granoblastic basalts with various recrystallization degrees (see "Description").

A

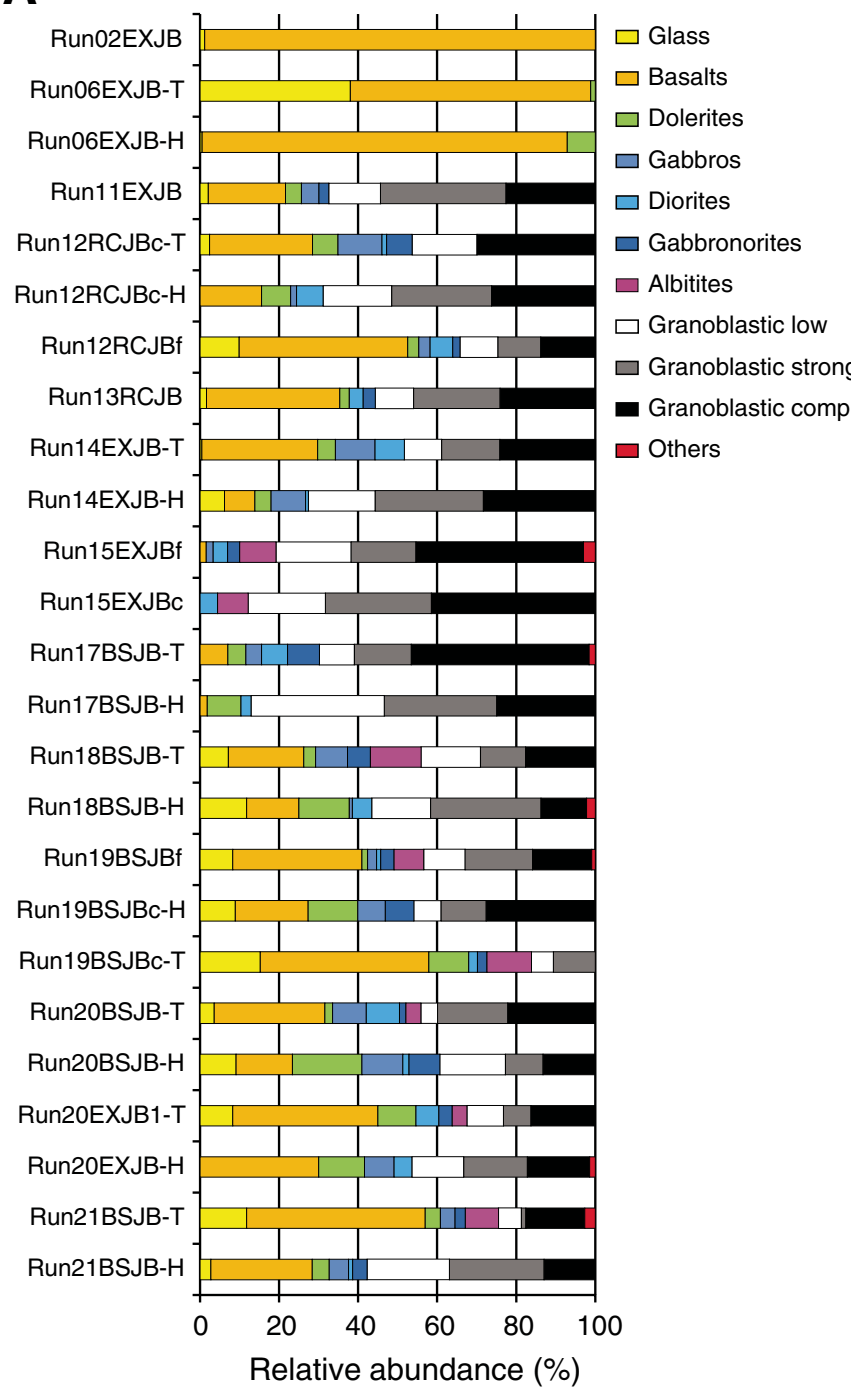

B

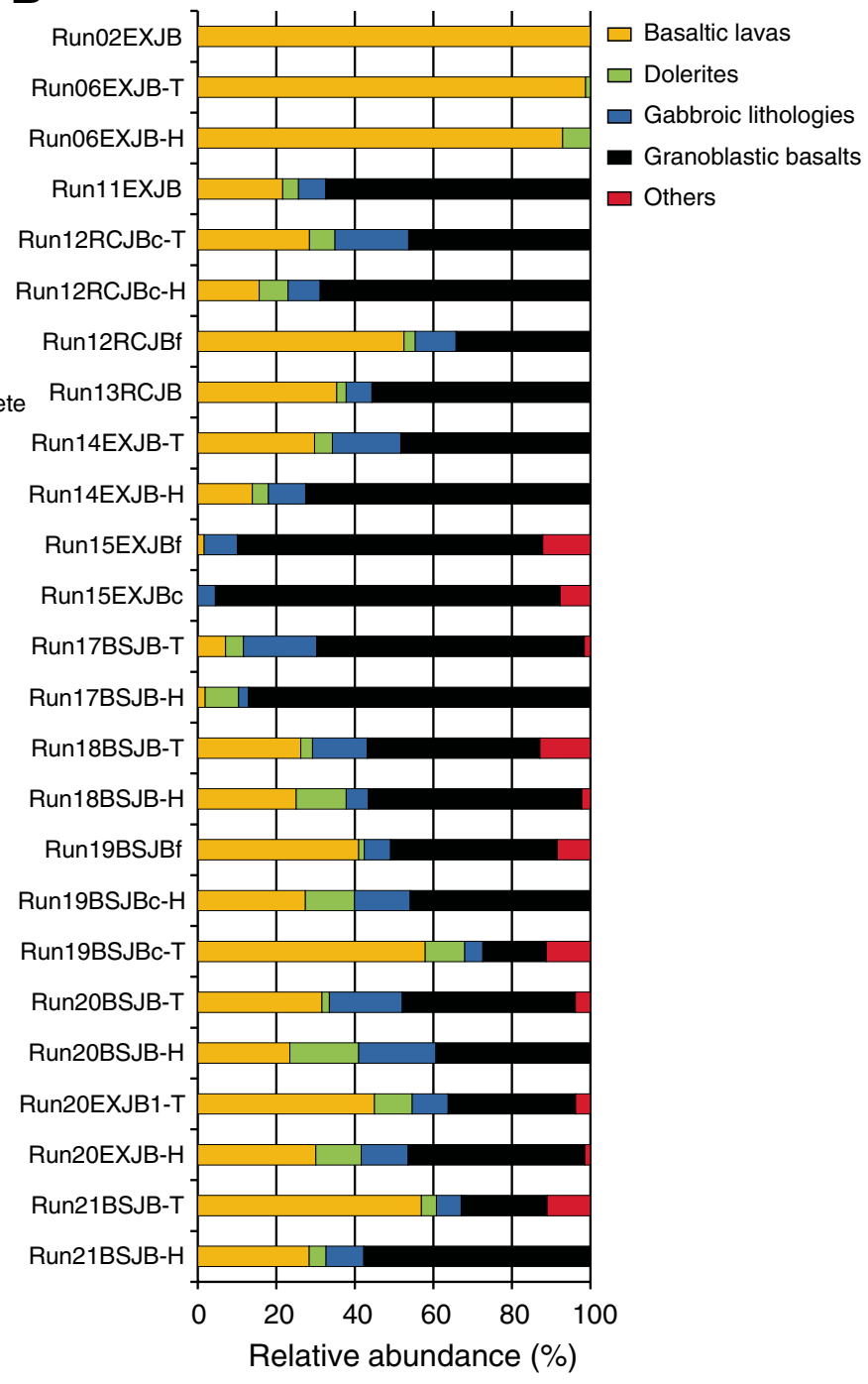


Figure F3. Composition of pyroxenes in (A) basaltic lavas and dolerites, (B) gabbroic lithologies and albitites, and (C) the different kinds of granoblastic basalt, Hole 1256D. In each diagram, the field of composition of other lithologies is illustrated. Wo = wollastonite, En = enstatite, Fs = ferrosillite, $\mathrm{Hd}=$ hedenbergite.
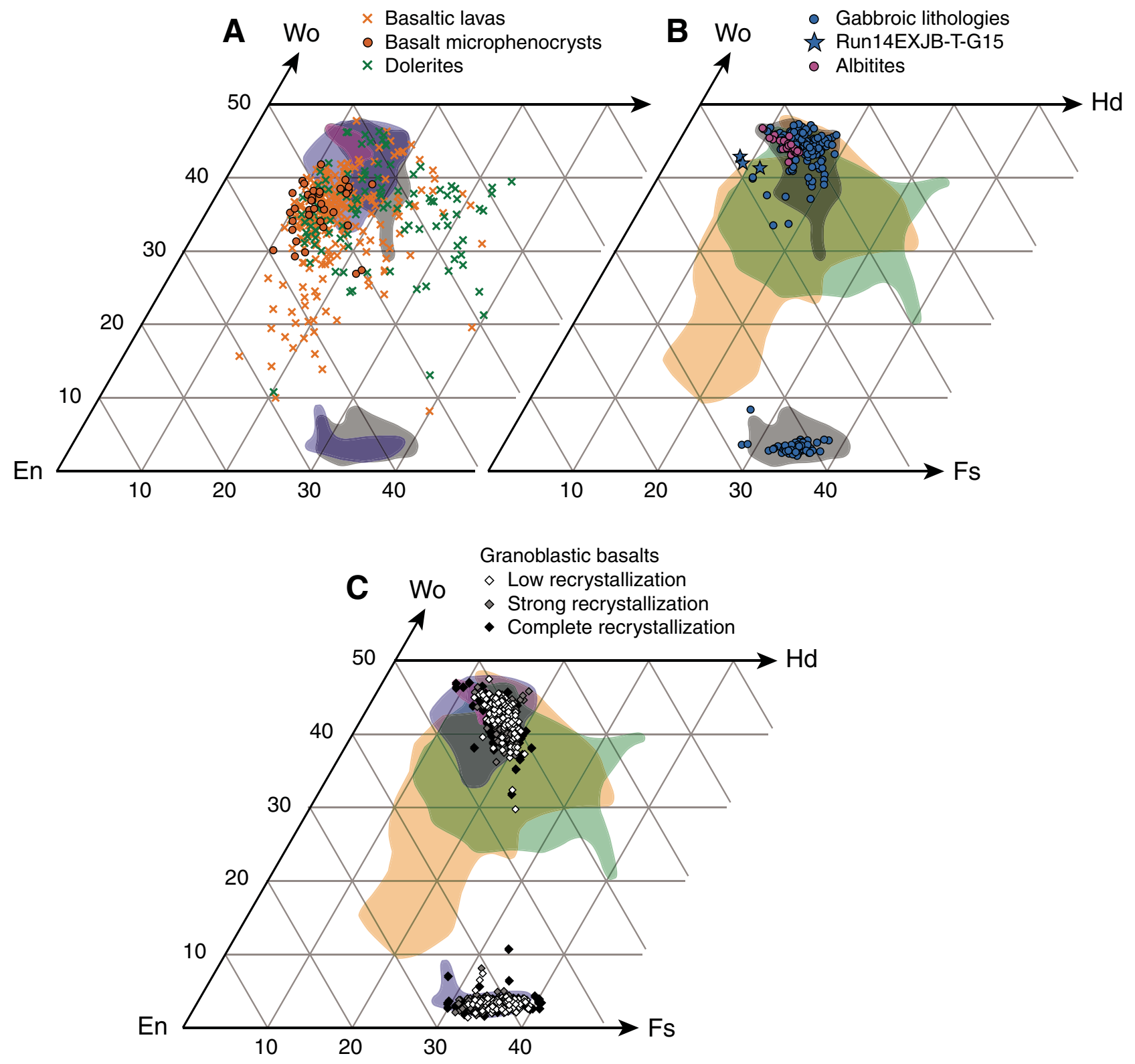
Figure F4. Variation of (A) $\mathrm{Cr}_{2} \mathrm{O}_{3},(\mathbf{B}) \mathrm{TiO}_{2},(\mathbf{C}) \mathrm{Al}_{2} \mathrm{O}_{3}$, and (D) $\mathrm{Na}_{2} \mathrm{O}$ vs. $\mathrm{Mg} \#\left(\left[\mathrm{Mg} /\left(\mathrm{Mg}+\mathrm{Fe}^{\mathrm{T}}\right)\right] \times 100\right)$ in clinopyroxenes (cpx) from the major lithologies, Hole 1256D. Run14EXJB-T-G15 gabbro and cpx microphenocrysts in basaltic lavas are distinguished for comparison purposes. Crosses = mean error bars for microprobe analyses.

A

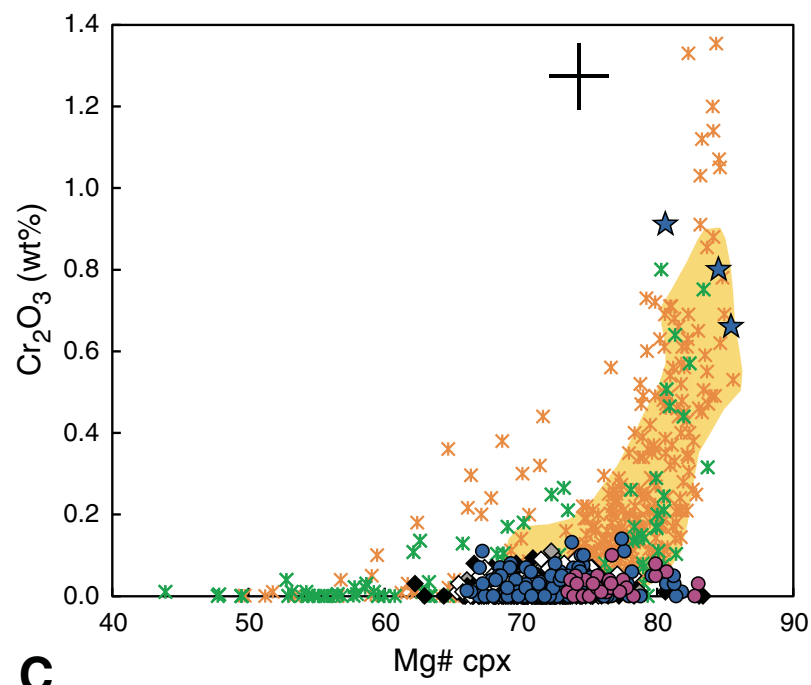

C

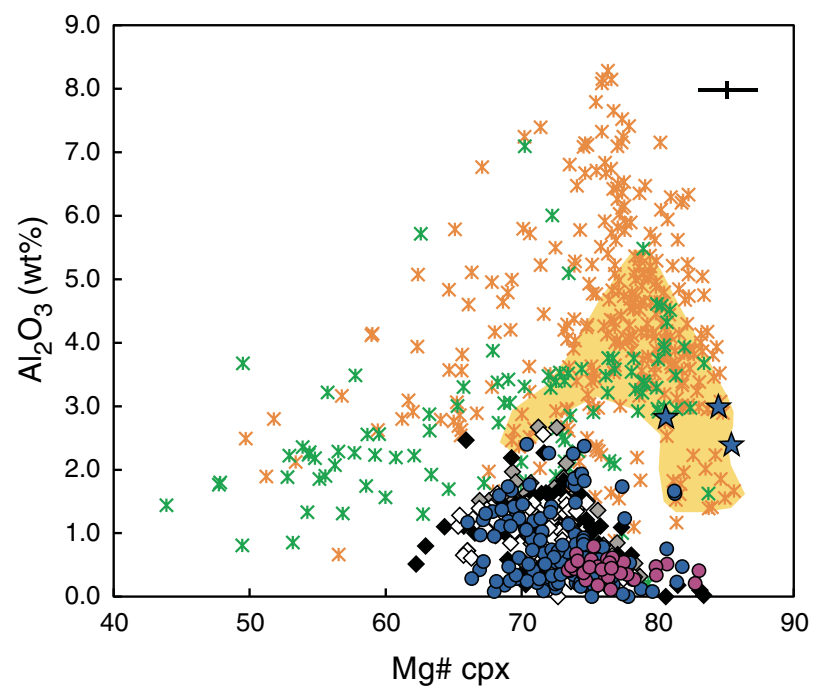

B
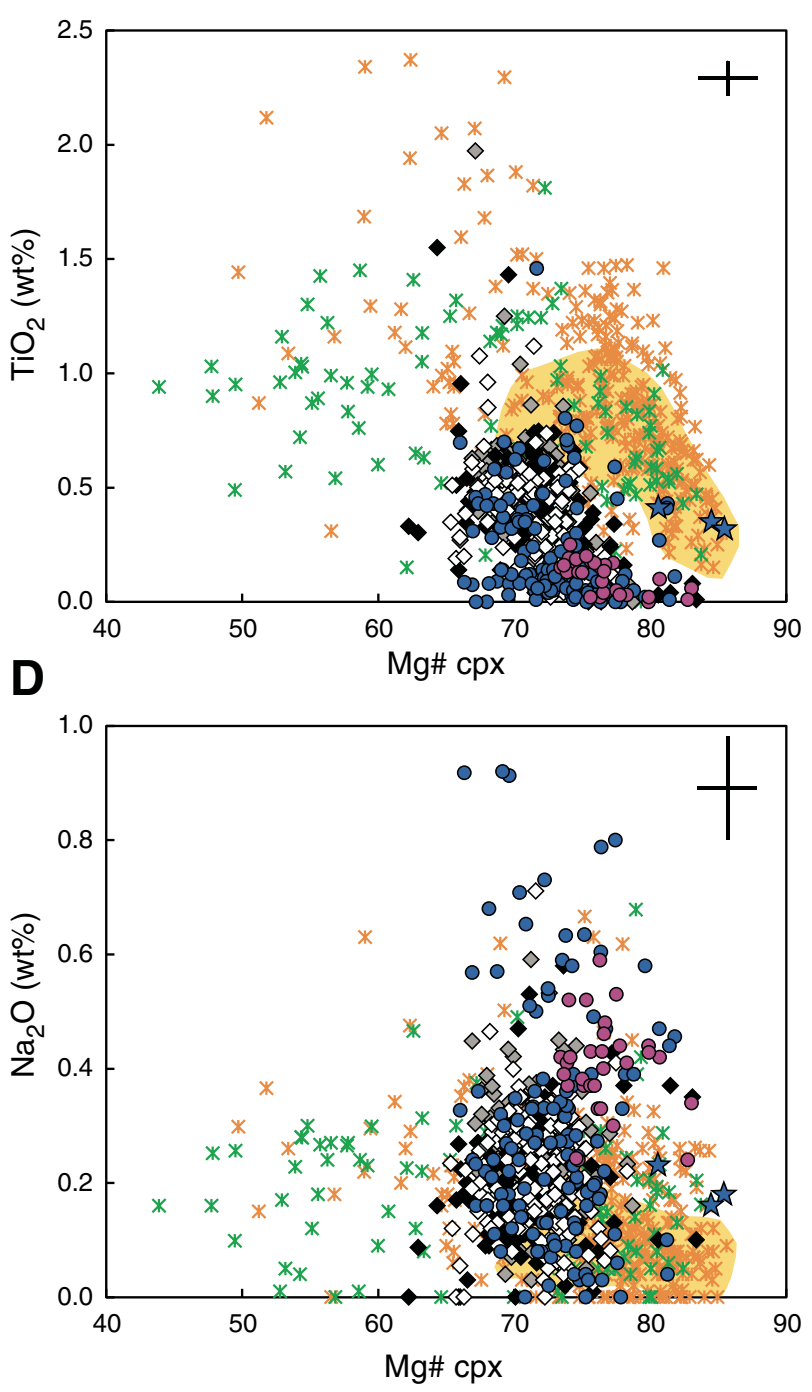

* Basaltic lavas

* Dolerites

- Gabbroic lithologies

- Albitites

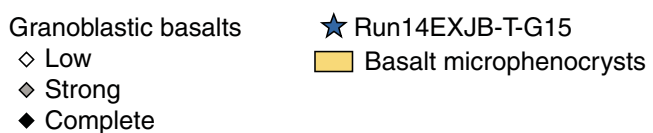


Figure F5. Variation of anorthite (An) content in plagioclase from the different lithologies, Hole 1256D. A. Histogram for main lithologic groups. Percentage of analyses for each lithologic group is indicated in the legend. B. Detailed histogram for basaltic lavas. C. Detailed histogram for gabbroic lithologies. D. Detailed histogram for granoblastic basalts. $\mathrm{Ol}=$ olivine.

\section{A}

B
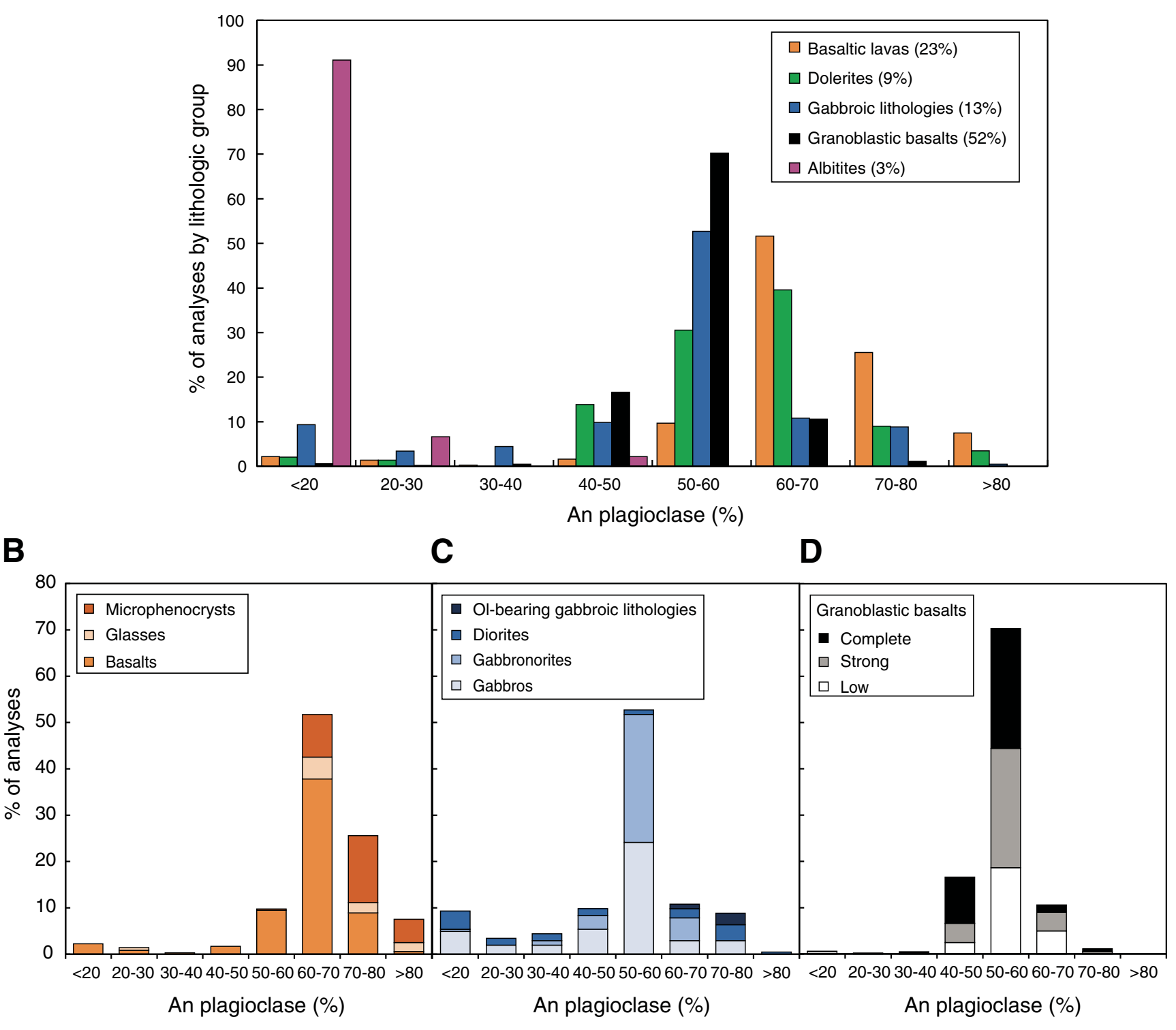
Figure F6. MgO vs. anorthite (An) content in plagioclases from major lithologies, Hole 1256D. Plagioclase microphenocrysts in basaltic lavas are distinguished for comparison purposes. Cross $=$ mean error bars for microprobe analyses.

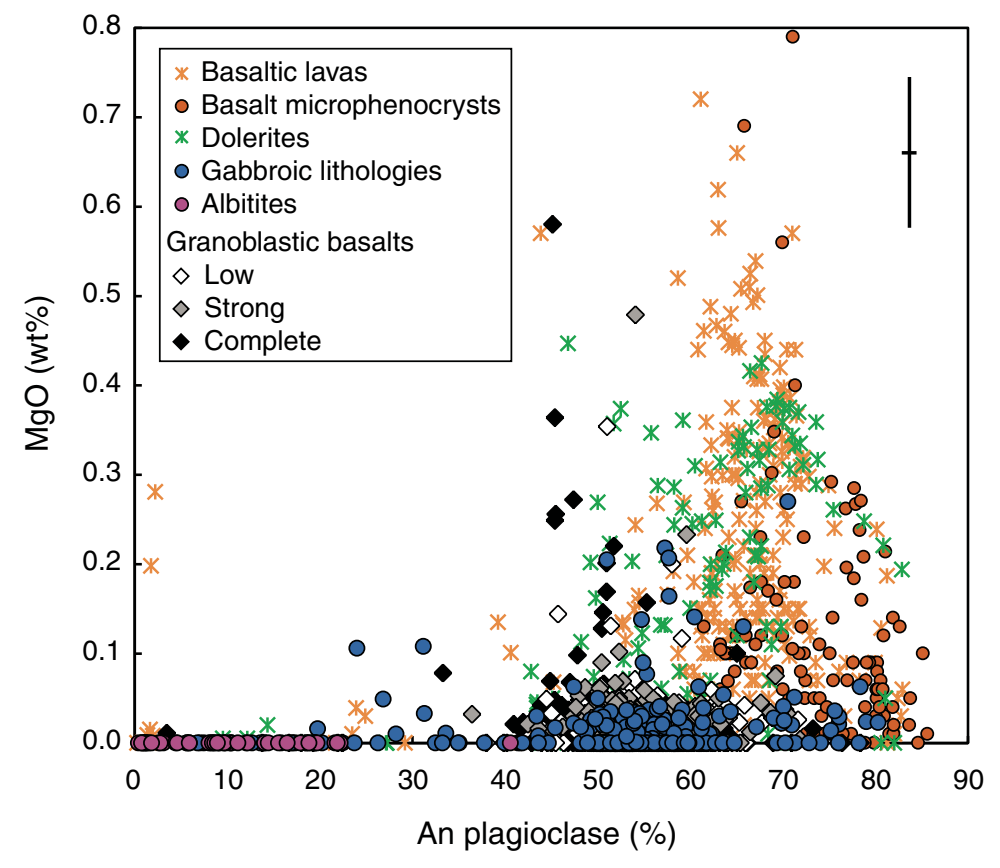


Figure F7. Composition of Fe-Ti oxides in major lithologic groups, Hole 1256D. A. FeO- $\mathrm{Fe}_{2} \mathrm{O}_{3}-\mathrm{TiO}_{2}$ ternary diagram including lines for ilmenite and magnetite solid solutions. $\mathbf{B} . \mathrm{Cr}_{2} \mathrm{O}_{3}$ vs. $\mathrm{TiO}_{2}$ in magnetites and titanomagnetites. Cross = mean error bars for microprobe analyses.

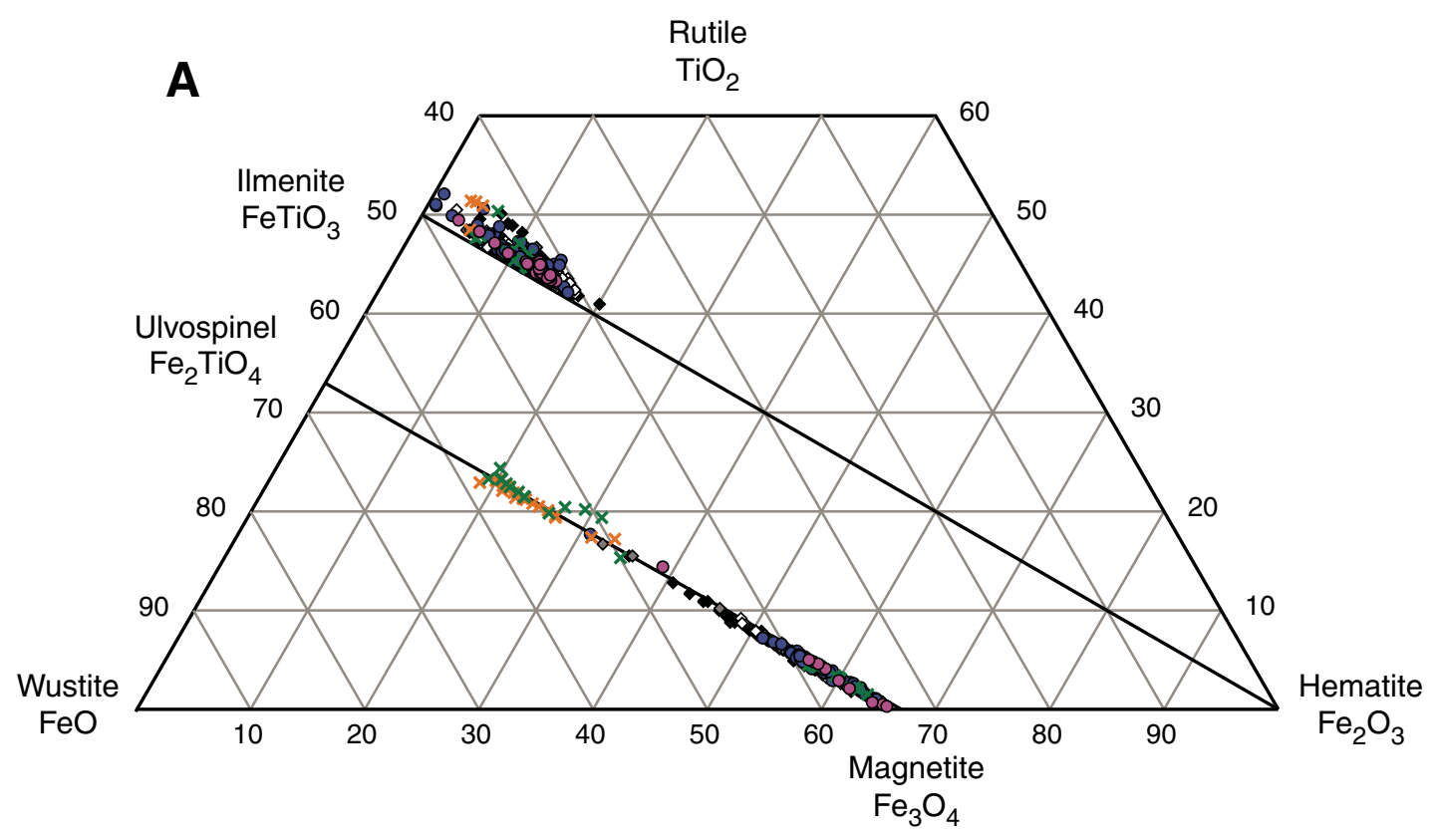

B

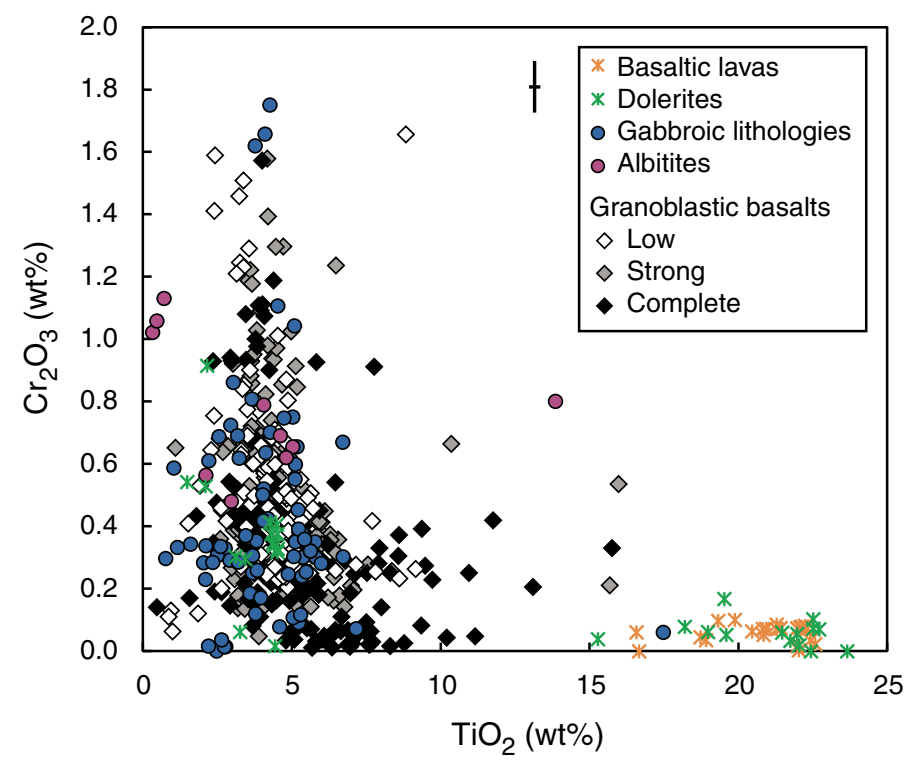


Figure F8. Composition of amphiboles in major lithologies according to the classification of Leake et al. (1997), Hole 1256D. A. Calcic amphiboles with $\mathrm{Ca}_{B} \geq 1.5,(\mathrm{Na}+\mathrm{K})_{\mathrm{A}}<0.5$, and $\mathrm{Ca}_{\mathrm{A}}<0.5$. B. Calcic amphiboles with $\mathrm{Ca}_{B}$ $\geq 1.5,(\mathrm{Na}+\mathrm{K})_{\mathrm{A}} \geq 0.5$, and $\mathrm{Ti}<0.5$. $\mathrm{Ca}, \mathrm{Na}, \mathrm{K}=$ atoms in the structural formula; $\mathrm{A}, \mathrm{B}=$ crystallographic sites.
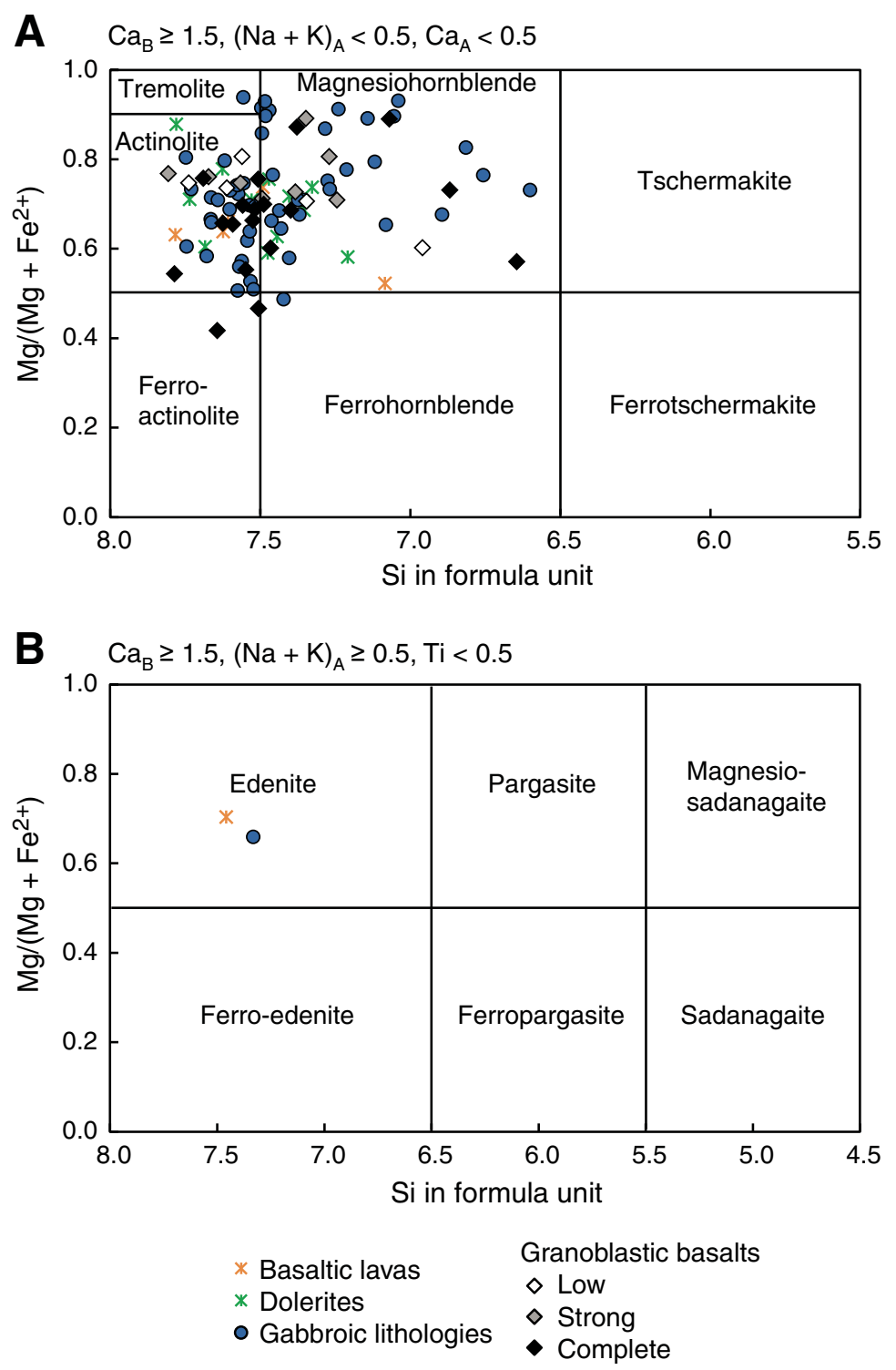
Figure F9. Composition of glasses in glass grains (fresh and devitrified glass) and in the groundmass of basalt and dolerite grains, Hole $1256 \mathrm{D}$. A. $\mathrm{CaO}$ vs. XMg. B. $\mathrm{Al}_{2} \mathrm{O}_{3}$ vs. XMg. C. $\mathrm{TiO}_{2}$ vs. $\mathrm{XMg}$. D. $\mathrm{Na}_{2} \mathrm{O}$ vs. $\mathrm{SiO}_{2} \cdot \mathrm{XMg}=$ $\mathrm{Mg} /\left(\mathrm{Mg}+\mathrm{Fe}^{\top}\right)$. Crosses = mean error bars for microprobe analyses.

A
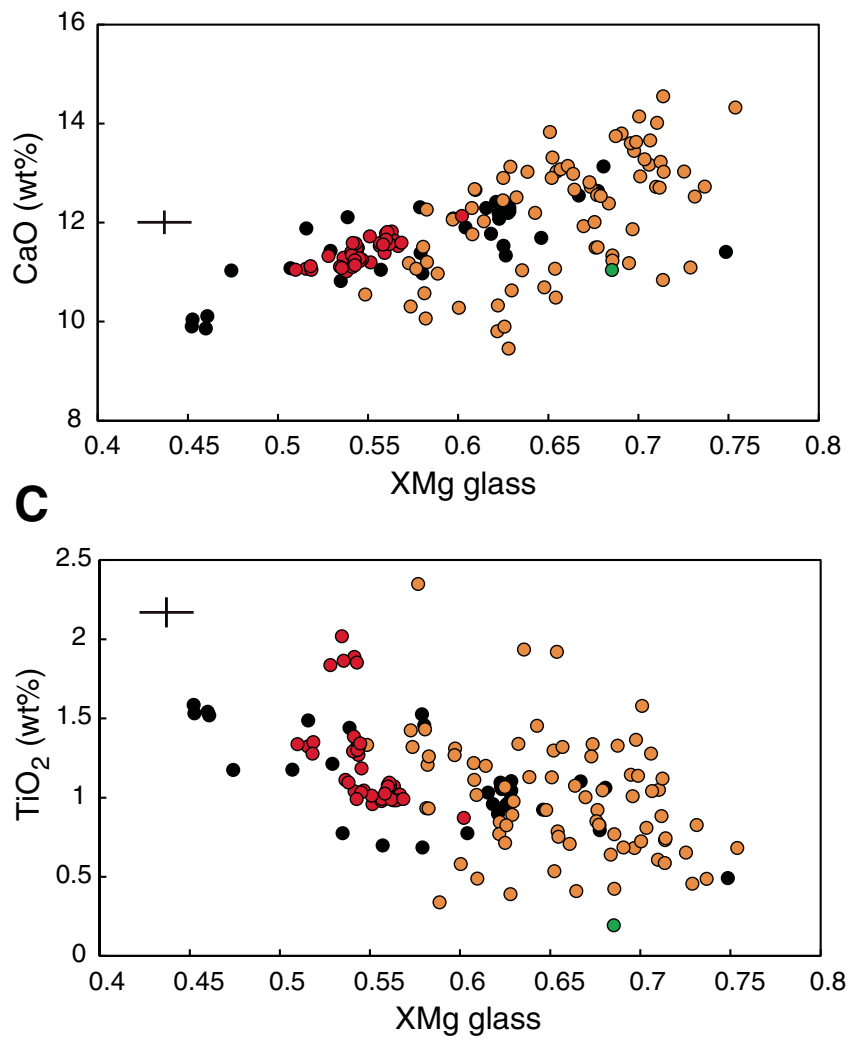

B
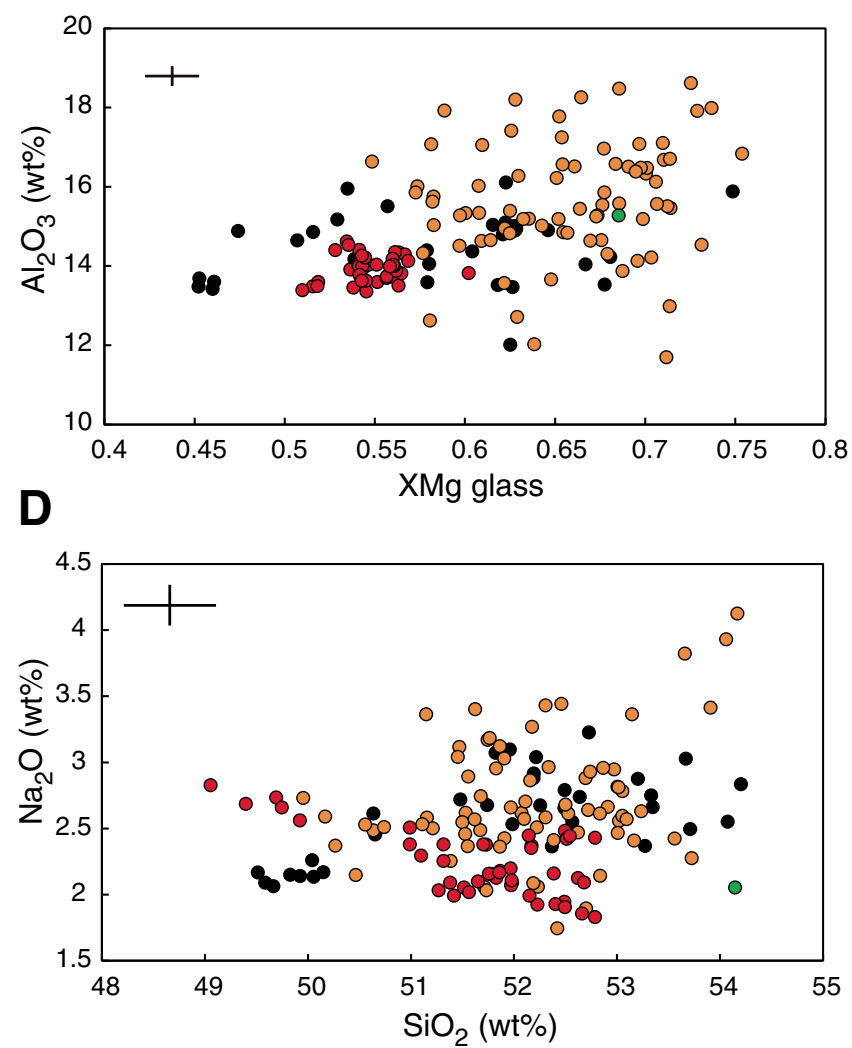
Table T1. Selected samples and characteristics of the corresponding thin sections, Hole $1256 \mathrm{D}$.

\begin{tabular}{|c|c|c|c|c|}
\hline $\begin{array}{l}\text { Fishing } \\
\text { run }\end{array}$ & Sample & $\begin{array}{l}\text { Thin } \\
\text { section }\end{array}$ & $\begin{array}{c}\text { Number of } \\
\text { grains }\end{array}$ & $\begin{array}{l}\text { Grain size } \\
\quad(\mathrm{mm})\end{array}$ \\
\hline 2 & Run02-EXJB & Run02EXJB & 36 & $0.9-3.2$ \\
\hline 6 & Run06-EXJB & $\begin{array}{l}\text { Run06EXJB-T } \\
\text { Run06EXJB-H }\end{array}$ & $\begin{array}{r}42 \\
400\end{array}$ & $\begin{array}{l}0.3-3.5 \\
0.1-3.2\end{array}$ \\
\hline 11 & Run11-EXJB & Run11EXJB & 35 & $1.2-4.2$ \\
\hline 12 & $\begin{array}{l}\text { Run12-RCJB C } \\
\text { Run12-RCJB f }\end{array}$ & $\begin{array}{l}\text { Run12RCJBC-T } \\
\text { Run12RCJBC-H } \\
\text { Run12RCJBf }\end{array}$ & $\begin{array}{l}24 \\
32 \\
31\end{array}$ & $\begin{array}{l}1.9-4.5 \\
0.9-6.2 \\
0.9-3.1\end{array}$ \\
\hline 13 & Run13-RCJB & Run13RCJB & 34 & $0.9-3.2$ \\
\hline 14 & Run14-EXJB & $\begin{array}{l}\text { Run14EXJB-T } \\
\text { Run14EXJB-H }\end{array}$ & $\begin{array}{l}35 \\
47\end{array}$ & $\begin{array}{l}0.6-3.6 \\
0.5-5.8\end{array}$ \\
\hline 15 & $\begin{array}{l}\text { Run15-EXJB f } \\
\text { Run15-EXJB C }\end{array}$ & $\begin{array}{l}\text { Run15EXJBf } \\
\text { Run15EXJBC }\end{array}$ & $\begin{array}{l}39 \\
27\end{array}$ & $\begin{array}{l}0.5-3.5 \\
1.9-3.4\end{array}$ \\
\hline 17 & Run17-BSJB & $\begin{array}{l}\text { Run17BSJB-T } \\
\text { Run17BSJB-H }\end{array}$ & $\begin{array}{l}27 \\
34\end{array}$ & $\begin{array}{l}0.7-4 \\
1.4-5\end{array}$ \\
\hline 18 & Run18-BSJB & $\begin{array}{l}\text { Run1 8BSJB-T } \\
\text { Run18BSJB-H }\end{array}$ & $\begin{array}{l}30 \\
42\end{array}$ & $\begin{array}{l}1.5-4.5 \\
0.7-3.7\end{array}$ \\
\hline 19 & $\begin{array}{l}\text { Run19-BSJB f } \\
\text { Run19-BSJB C }\end{array}$ & $\begin{array}{l}\text { Run19BSJBf } \\
\text { Run19BSJBC-H } \\
\text { Run19BSJBC-T }\end{array}$ & $\begin{array}{l}39 \\
35 \\
28\end{array}$ & $\begin{array}{l}1.1-3 \\
0.6-5.7 \\
2-4.3\end{array}$ \\
\hline 20 & $\begin{array}{l}\text { Run20-BSJB } \\
\text { Run20-EXJB1 }\end{array}$ & $\begin{array}{l}\text { Run20BSJB-T } \\
\text { Run20BSJB-H } \\
\text { Run20EXJB1-T } \\
\text { Run20EXJB1-H }\end{array}$ & $\begin{array}{r}31 \\
62 \\
36 \\
168\end{array}$ & $\begin{array}{l}1.4-3.6 \\
0.7-4.5 \\
0.9-4.1 \\
0.1-4.3\end{array}$ \\
\hline 21 & Run21-BSJB & $\begin{array}{l}\text { Run21BSJB-T } \\
\text { Run21BSJB-H }\end{array}$ & $\begin{array}{l}36 \\
46\end{array}$ & $\begin{array}{l}1.5-3.7 \\
0.4-5.5\end{array}$ \\
\hline
\end{tabular}

EXJB, RCJB, and BSJB refer to different fishing assemblies; see Table T1 in the "Site 1256" chapter (Expedition 335 Scientists, $2012 \mathrm{c}$ ) for more information. $\mathrm{C}=$ coarser fraction, $\mathrm{f}=$ finer fraction. $\mathrm{T}$ and $\mathrm{H}$ are thin sections prepared in duplicate. 
Table T2. Thermometry and oxybarometry results, Hole 1256D.

\begin{tabular}{|c|c|c|c|c|c|c|c|c|c|c|c|c|c|c|c|c|}
\hline \multirow[b]{2}{*}{ Lithology } & \multicolumn{2}{|c|}{ Single-cpx } & \multicolumn{2}{|c|}{ 2-pyroxene } & \multicolumn{3}{|c|}{ QUILF 2-pyroxene } & \multicolumn{2}{|c|}{ Amph-pl } & \multicolumn{3}{|c|}{ 2-oxide } & \multicolumn{4}{|c|}{ QUILF 2-oxide } \\
\hline & $N$ & $T\left({ }^{\circ} \mathrm{C}\right)$ & $N$ & $T\left({ }^{\circ} \mathrm{C}\right)$ & $\mathrm{N}$ & $T\left({ }^{\circ} \mathrm{C}\right)$ & $T$ err $\left({ }^{\circ} \mathrm{C}\right)$ & $N$ & $T\left({ }^{\circ} \mathrm{C}\right)$ & $N$ & $T\left({ }^{\circ} \mathrm{C}\right)$ & $\triangle \mathrm{NNO}$ & $N$ & $T\left({ }^{\circ} \mathrm{C}\right)$ & $T$ err $\left({ }^{\circ} \mathrm{C}\right)$ & $\Delta \mathrm{FMQ}$ \\
\hline Basalts & & & & & & & & & & 1 & 798 & -1.26 & 1 & 689 & 103 & -1.44 \\
\hline Dolerites & 28 & 1017 & & & & & & 1 & 707 & 3 & 902 & -0.80 & 3 & 716 & 97 & 0.91 \\
\hline Diorites & 7 & 799 & 1 & 783 & 1 & 909 & 46 & 2 & 887 & & & & & & & \\
\hline Gabbros & 16 & 809 & & & & & & 6 & 817 & 11 & 622 & 2.27 & 11 & 674 & 76 & 1.92 \\
\hline Gabbronorites & 13 & 810 & 12 & 816 & 12 & 958 & 55 & & & 10 & 643 & 2.04 & 10 & 697 & 119 & 1.86 \\
\hline Albitites & 9 & 780 & & & & & & & & 2 & 611 & 2.66 & 2 & 677 & 12 & 2.57 \\
\hline Granoblastic basalts (Degree 1) & 15 & 833 & 10 & 852 & 10 & 966 & 52 & & & 8 & 632 & 2.38 & 8 & 684 & 70 & 2.22 \\
\hline Granoblastic basalts (Degree 2) & 30 & 838 & 25 & 857 & 25 & 969 & 45 & 2 & 744 & 17 & 637 & 2.15 & 17 & 694 & 70 & 2.01 \\
\hline Granoblastic basalts (Degree 3 ) & 26 & 861 & 21 & 882 & 21 & 984 & 42 & 2 & 863 & 16 & 632 & 2.05 & 16 & 679 & 117 & 1.71 \\
\hline Granoblastic basalts (Degree 4) & 22 & 854 & 18 & 877 & 18 & 974 & 44 & 1 & 756 & 12 & 631 & 1.97 & 12 & 681 & 75 & 1.49 \\
\hline Granoblastic basalts (Degree 5) & 34 & 855 & 29 & 880 & 29 & 977 & 46 & 3 & 776 & 23 & 644 & 2.00 & 23 & 696 & 103 & 1.83 \\
\hline Granoblastic basalts (Degree 6) & 17 & 845 & 13 & 888 & 13 & 985 & 52 & 1 & 712 & 12 & 640 & 2.11 & 12 & 688 & 94 & 1.91 \\
\hline Run14EXJB-T-G15 gabbro & 1 & 996 & & & & & & & & & & & & & & \\
\hline Ol-gabbronorite & 1 & 895 & 1 & 980 & 1 & 1040 & 131 & & & & & & & & & \\
\hline
\end{tabular}

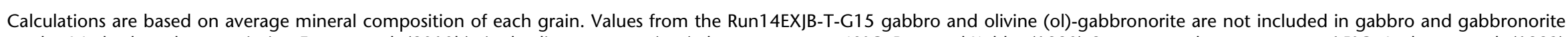

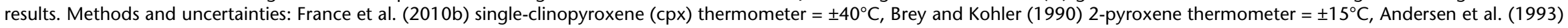
QUILF 2-pyroxene thermometer and QUILF 2-oxide oxythermobarometer $= \pm 0.1$ log units, Holland and Blundy (1994) amphibole (amph)-plagioclase (pl) thermometer $= \pm 40^{\circ} \mathrm{C}$, Sauerzapf et al. (2008) 2-oxide oxythermobarometer $= \pm 70^{\circ} \mathrm{C}$ and $\pm 0.4 \mathrm{log}$ units. France et al. (2010a) clinopyroxene-plagioclase oxybarometer used temperatures estimated with $*=$ single-cpx, $\dagger=2$ -

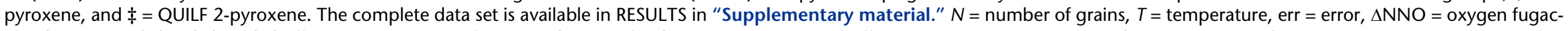
ity relative to nickel-nickel-oxide buffer, $\Delta \mathrm{FMQ}=$ oxygen fugacity relative to fayalite-magnetite-quartz buffer, $\Delta \mathrm{FMQ}$ err $=2 \sigma$ error according to France et al. (2010a).

\begin{tabular}{|c|c|c|c|c|c|c|c|c|c|c|c|c|}
\hline \multirow[b]{2}{*}{ Lithology } & \multicolumn{4}{|c|}{ Clinopyroxene-plagioclase ${ }^{*}$} & \multicolumn{4}{|c|}{ Clinopyroxene-plagioclase $^{\dagger}$} & \multicolumn{4}{|c|}{ Clinopyroxene-plagioclase ${ }^{\ddagger}$} \\
\hline & $N$ & $\Delta \mathrm{FMQ}$ & $\triangle \mathrm{FMQ}$ err & $\triangle \mathrm{NNO}$ & $N$ & $\Delta \mathrm{FMQ}$ & $\triangle \mathrm{FMQ}$ err & $\triangle \mathrm{NNO}$ & $N$ & $\triangle \mathrm{FMQ}$ & $\triangle \mathrm{FMQ}$ err & $\triangle \mathrm{NNO}$ \\
\hline \multicolumn{13}{|l|}{ Basalts } \\
\hline Dolerites & 25 & 1.95 & 0.68 & 1.22 & 25 & & & & 25 & & & \\
\hline Diorites & 3 & 1.11 & 1.02 & 0.33 & 3 & & & & 3 & & & \\
\hline Gabbros & 11 & 1.27 & 1.03 & 0.49 & 11 & & & & 11 & & & \\
\hline Gabbronorites & 13 & & & & 13 & 0.93 & 1.07 & 0.14 & 13 & 0.78 & 1.15 & 0.03 \\
\hline Granoblastic basalts (Degree 1) & 14 & & & & 14 & 1.20 & 0.92 & 0.45 & 14 & \multicolumn{3}{|c|}{ Albitites } \\
\hline Granoblastic basalts (Degree 2) & 29 & & & & 29 & 0.80 & 1.08 & 0.03 & 29 & 0.66 & 1.14 & -0.08 \\
\hline Granoblastic basalts (Degree 3) & 26 & & & & 26 & 0.82 & 1.05 & 0.05 & 26 & 0.68 & 1.11 & -0.06 \\
\hline Granoblastic basalts (Degree 4) & 22 & & & & 22 & 0.92 & 1.03 & 0.15 & 22 & 0.79 & 1.09 & 0.05 \\
\hline Granoblastic basalts (Degree 5) & 34 & & & & 34 & 0.98 & 0.97 & 0.22 & 34 & 0.86 & 1.02 & 0.12 \\
\hline Granoblastic basalts (Degree 6) & 16 & & & & 16 & 1.35 & 0.88 & 0.58 & 16 & 1.23 & 0.93 & 0.49 \\
\hline Run14EXJB-T-G15 gabbro & 1 & 3.02 & 0.74 & 2.28 & 1 & & & & 1 & & & \\
\hline Ol-gabbronorite & 1 & & & & 1 & 2.07 & 0.87 & 1.32 & 1 & 1.97 & 0.99 & 1.25 \\
\hline
\end{tabular}

